\title{
Trichodesmium and other planktonic cyanobacteria in New Caledonian waters (SW tropical Pacific) during an EI Niño episode
}

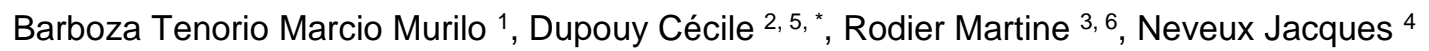

\begin{abstract}
1 Univ Fed Rio de Janeiro UFRJ, Inst Biol, Lab Plancton Marinho, Ave Brigadeiro Trompowsky SN,CCS,BL A,SL 79, BR-20530310 Rio De Janeiro, RJ, Brazil.

2 Univ Toulon \& Var, Aix Marseille Univ, CNRS, Inst Rech Dev,Mediterranean Inst Oceanog,UM 110, Batiment Mediterranee,Campus Luminy, F-13288 Marseille, France.

3 Univ Polynesie Francaise, Inst Rech Dev, Inst Louis Malarde, Ifremer,UMR Ecosyst Insulaires Oceaniens 241, F-98713 Papeete, French Polynesi, Fr Polynesia.

${ }^{4}$ CNRS UPMC, Observ Oceanol Banyuls, LOMIC UMR 7621, Ave Pierre Fabre, F-66650 Banyuls Sur

Mer, France.

${ }^{5}$ Ctr IRD Noumea, BP A5, Noumea 98848, New Caledonia.

${ }^{6}$ Ctr IRD Tahiti, BP 529, F-98713 Papeete, Fr Polynesia.
\end{abstract}

* Corresponding author : Cécile Dupouy, email address : cecile.dupouy@mio.osupytheas.fr

\begin{abstract}
:
Contributions of filamentous and picoplanktonic cyanobacteria to the phytoplankton community structure were examined in New Caledonian waters during the 2001-2003 El Niño period at 2 ocean stations (Loyalty Channel and Santal Bay) and 1 coral-reef lagoon station (Ouinne). Morphometric characteristics of diazotrophic filamentous cyanobacteria are given, as well as the seasonal and inter-annual variations of their surface areas and integrated abundances. Trichodesmium tenue and T. thiebautii were the dominant species followed by T. erythraeum, altogether accounting for more than $51-80 \%$ of the biomass of the free-living filamentous cyanobacteria. Katagnymene spp. accounted for a smaller percentage $(<13.8 \%$ at ocean stations, $<3.6 \%$ in the lagoon). Richelia intracellularis biomass was relatively small $(<1 \%$ of total surface area and volume of Trichodesmium trichomes), with the highest concentration observed in summer (735 trichomes 1-1). Colonies of unidentified cyanobacteria composed of spherical cells accounted on average for $<1 \%$ of the Trichodesmium biomass, with maximum values exceeding 4000 cells $1-1$. Abundance of filamentous cyanobacteria varied according to environmental factors; summer 2001-2002 was characterized by low filamentous diazotroph abundance, and summer 2003, at the peak of the 2001-2003 El Niño, was particularly rich in filamentous cyanobacteria (with a maximum Trichodesmium spp. abundance of 4500 trichomes $\mathrm{I}-1$ in the Loyalty Channel). A similar variability pattern was observed for large diatoms and dinoflagellates, and for all picoeukaryotic populations. Different biomass estimators are provided, including cell abundances, pigment concentrations including chlorophylls and phycoerythrin, and carbon content.
\end{abstract}


Keywords : Trichodesmium, Filamentous cyanobacteria, Community structure, Microscopy, Picoplankton, Pigments, Loyalty Islands, Coral-reef lagoon, El Nino 
In the Oceans, most of the subtropical and tropical pelagic areas are dominated by 51 oligotrophic conditions and picophytoplankton, which are best adapted to nutrient-poor

52 environments (Buitenhuis et al. 2012a, Luo et al. 2012). Unicellular picoplanktonic cyanobacteria

53 are certainly the most abundant photosynthetic group and distributed throughout the tropical

54 Pacific Ocean (Le Bouteiller et al. 1992, Ishizaka et al. 1994, Buitenhuis et al. 2012b). Other

55 marine cyanobacteria, comparatively patchier and less abundant, also play a pivotal role in $\mathrm{N}$ -

56 limited ecosystems, combining primary production and dissolved $\mathrm{N}_{2}$ fixation (diazotrophy). This

57 cyanobacterial diazotrophic community includes unicellular, filamentous, and symbiotic forms

58 (Luo et al. 2012, Bergman et al. 2013). Pelagic filamentous cyanobacteria consist mainly of the

59 Trichodesmium genus with two more frequently reported and quantified species: T. erythraeum

60 Ehrenberg and T. thiebautii Gomont. Three other Trichodesmium species (T. tenue Wille, $T$.

61 contortum Wille and T. hildebrandtii Gomont), and two Katagnymene species (K. pelagica and

62 K. spiralis Lemmerman) are more scarcely reported. Furthermore, Richelia intracellularis has

63 been regarded as one of the main tropical filamentous diazotrophs in marine pelagic waters

64 forming large blooms in some regions as parts of Diatom-Diazotrophic Associations (DDAs).

65 This heterocystous cyanobacterium is usually observed as an endosymbiont of the Rhizosolenia

66 (sometimes referred as Het1 or RR) and Hemiaulus (Het-2 or HR) (Venrick 1974, Janson et al. 
1999) diatoms and has also been reported as an epiphyte of Chaetoceros spp. (Gómez et al. 2005) or a free-living filament. The epiphytic form was identified as a separate species, Calothrix rhizosoleniae, based on genetic characterization (Janson et al. 1999, Foster et al. 2010). It has also been reported in cohabitation with Trichodesmium puff-form colonies (Jabir et al. 2013, Momper et al. 2015, Giraud et al. 2016). Besides Trichodesmium and other filamentous cyanobacteria, free-living unicellular cyanobacteria (UCYN-A, -B, and -C) are also recognized as possible major diazotrophs in tropical and subtropical areas (Zehr \& Bombar 2015), occupying different ecological niches.

$\mathrm{N}_{2}$ fixation by filamentous cyanobacteria in the oceans is estimated at around $80 \mathrm{Tg} \mathrm{N}$ per year (Capone et al. 1997) for a global oceanic $\mathrm{N}_{2}$ fixation of 100-200 Tg N per year (Karl et al. 2002) and accounts for more than $70 \%$ of global marine $\mathrm{N}_{2}$ fixation (Luo et al. 2012, Bergman et al. 2013). The Southern Tropical Pacific is a region known for high $\mathrm{N}_{2}$ fixation, as measured between New Caledonia and Vanuatu (Garcia et al. 2007, Masotti et al. 2007, Biegala et al. 2014), over a longitudinal transect at $17^{\circ} \mathrm{S}$ (Shiozaki et al. 2014) and in the lagoon (Biegala \& Raimbault 2008, Bonnet et al. 2016). Surface blooms are frequently observed in the region, mainly composed of filamentous cyanobacteria (Dupouy et al. 2011).

Identification and counts of filamentous cyanobacteria at the species level are nevertheless scarce (Campbell et al. 2005, Luo et al. 2012) as recent work relies only on Nifh gene counts (Moisander et al. 2010, Bonnet et al. 2015, 2016). Moreover, few studies address their temporal variability as reported at HOT in the Northern Pacific (Letelier \& Karl 1996), BATS in the Northern Atlantic (Orcutt et al. 2001), and in the Indian Ocean (Lugomela et al. 2002).

By quantifying the different species abundances and their specific relationship with nutrient and physical environmental conditions, it should be possible to more precisely identify the main factors stimulating filamentous cyanobacterial growth and how they affect the community structure. Such data are essential for estimating global $\mathrm{N}_{2}$ fixation more accurately, improving our understanding of how $\mathrm{N}_{2}$ fixing species respond to their environment, and anticipating how the phytoplankton community will develop in the context of global climate change (Dutkiewicz et al. 2015, Gruber 2016). In situ abundance of filamentous cyanobacteria and their content in pigment are also needed to calibrate recent bio-optical models aiming to determine their abundance from light reflectance of surface mats (Dupouy et al. 2011, Gower et al. 2014, McKinna 2015) or medium concentration blooms (Westberry \& Siegel 2006, De Boissieu et al., 2014). 
A careful study of the seasonal and inter-annual variations of different filamentous cyanobacteria species abundances was undertaken in 2001-2003 (Diapalis program) in New

101 Caledonian waters and tentatively analyzed based on changes in environmental conditions and in the abundance of other components of the autotrophic community, particularly picoplankton. For this paper, data were obtained at three stations: an open-ocean station (Loyalty Channel), a large, deep and open bay (Santal Bay, Lifou Island) and a lagoon station (Ouinne, southeast coral reef lagoon). Taxonomic identification, measurements and counts of filamentous species were carried out by microscopy while data on picoplankton were analyzed by flow cytometry. The various estimators for determining filamentous cyanobacterial biomass were also compared. Nutrient data (Van Den Broeck et al. 2004, Moutin et al. 2005) and all $\mathrm{N}_{2}$ fixation rates measured under the Diapalis program had been published earlier (Garcia et al. 2007).

\section{MATERIAL AND METHODS}

113 Sampling and environmental data. Nine oceanographic cruises (Diapalis program: D1 to D9)

114 lasting about a week each were conducted between October 2001 and October 2003 aboard IRD's

115 R.V. Alis between $165^{\circ} \mathrm{E}$ and $168^{\circ} \mathrm{E}$ and between $20^{\circ} \mathrm{S}$ and $23^{\circ} \mathrm{S}$ in the Eastern Coral Sea (Table

116 1, Fig 1). Samples were taken at three stations: the first at $167^{\circ} 30^{\prime} \mathrm{E} 20^{\circ} 30^{\prime} \mathrm{S}$ in the deep Santal

117 Bay which is broadly exposed to the ocean, on Lifou Island's west coast (bottom depth: $1050 \mathrm{~m}$,

$118 \mathrm{ST} 1$ ), the second in open ocean waters in the middle of the Loyalty Channel at $21^{\circ} 30^{\prime} \mathrm{S} 167^{\circ} \mathrm{E}$

119 (bottom depth: $2000 \mathrm{~m}, \mathrm{ST} 2)$, and the third (166 $\left.45^{\prime} \mathrm{E} 21^{\circ} 57^{\prime} \mathrm{S}\right)$ in the south eastern coral-reef

120 lagoon of New Caledonia (bottom depth: $40 \mathrm{~m}$, ST3). The sampling covered different seasons

121 (Table 1): summers 2002 (D2 to D4) - 2003 (D7), winters 2002 (D6) - 2003 (D8) and transition

122 periods (D1, D5, D9). A sample was also collected from a surface accumulation of

123 Trichodesmium erythraeum located in New Caledonia's southwestern lagoon.

124 During cruises, CTD casts were carried out at each station with water sampling down to $200 \mathrm{~m}$ 125 for the deepest stations and down to $30 \mathrm{~m}$ in the lagoon. Temperature $\left(\mathrm{T}^{\circ} \mathrm{C}\right)$ and salinity were 126 measured with Sea-Bird SBE 911 and water samples were collected with 8L-Niskin bottles 127 attached to a CTD-rosette system. Nitrate + nitrite $\left(\mathrm{NO}_{\mathrm{x}}\right)$ and phosphate $\left(\mathrm{PO}_{4}^{3-}\right)$ were preserved 128 in Nalgene bottles with $\mathrm{HgCl}_{2}$ prior colorimetric assays on a Technicon autoanalyzer II 129 (Raimbault et al. 1990). Ammonium was measured immediately on board by fluorometry (Turner 130 Design TD-700) according to the procedure described in Holmes et al. (1999). More details on 
131 the methods and the full data set Diapalis are available on http://www.obs132 vlfr.fr/proof/vt/op/ec/diapazon/dia.htm. The mixed layer depth (MLD) was estimated by taking 133 the first depth where potential density (sigma-t) was $0.03 \mathrm{Kg} \mathrm{m}^{-3}$ greater than the density at 10 meters, based on Montegut et al. (2004).

Filamentous cyanobacteria counting and morphometric characteristics. Filamentous cyanobacteria were recovered from water samples taken at 4-6 depths down to $80 \mathrm{~m}$, with a rosette of $8 \mathrm{~L}$ Niskin bottles. Organisms were collected by filtering whole water bottles through a $10 \mu \mathrm{m}$ Nuclepore polycarbonate membrane. The filter was then placed in a $20 \mathrm{~mL}$ glass bottle containing a $4 \%$ formalin solution for preserving photosynthetic organisms. In the laboratory, the filter was rinsed with a plastic wash bottle containing filtered seawater in order to remove all the organisms from the filter and collect them in a $100 \mathrm{~mL}$ glass cylinder. After processing, the filter was checked for any remaining photosynthetic organisms. A suitable quantity of an acidic formalin solution (1/1 mixture of $40 \%$ formalin and acetic acid) was then added to obtain organisms in a final $0.4 \%$ formalin solution. From this solution, filamentous cyanobacteria and other large phytoplanktonic species were measured and enumerated with an inverted microscope (OLYMPUS IM., 100× magnification) using a standard sedimentation technique (Utermöhl 1931). According to Cronberg et al. (2004), the acetic acid breaks the gas vesicles facilitating the sedimentation of filaments in the sedimentation chambers. Sedimentation time was 24 hours in 5 and $10 \mathrm{~mL}$ chambers and at least 48 hours for the 25 and $50 \mathrm{~mL}$ chambers, depending on cell and filament abundances. A total of 88 samples were examined for the 9 cruises. For surface accumulations of Trichodesmium erythraeum, samples were collected directly by hand with a small bottle $(500 \mathrm{~mL})$, which was then processed using the same method as described above.

Identification of the filamentous Trichodesmium, Katagnymene (see review in Bergman et al. 2013) and Richelia (Foster et al. 2010) was carried out based on their morphological characteristics. Cell shape and dimensions (particularly cell diameter) were the main criteria used for classifying and identifying them. The sample processing method used to facilitate enumeration and morphometric examination at trichome level could not be used for observations at colony level, because most of them had disintegrated. Trichome surface and volume were then calculated on the assumption that they had an elongated cylindrical morphology. For $T$. erythraeum and T. thiebautii, identification was confirmed by molecular biology studies (unp. data). Colonies of unidentified cyanobacteria composed of spherical cells were also observed and 
enumerated.

164 Photosynthetic pigment analysis by spectrofluorometry. Chlorophylls including divinyl-chl $a$ 165 and $b$ for Prochlorococcus were measured by spectrofluorometry (F4500 HITACHI 166 spectrofluorometer) based on Neveux \& Lantoine (1993) and Tenório et al. (2005). From 0.25 to $1670.5 \mathrm{~L}$, water samples were filtered on $25 \mathrm{~mm} \mathrm{GF} / \mathrm{F}$ for the chlorophylls analysis in the total community. Chlorophylls were extracted in $90 \%$ acetone after grinding the GF/F filter. Measurements in the $>10 \mu \mathrm{m}$ fraction of the community were also carried out by filtering a whole 8L Niskin bottle through $47 \mathrm{~mm}$ Nuclepore polycarbonate membranes. In the latter case, chlorophylls were extracted in 90 \% Dimethylformamide (DMF) without grinding the membrane. For convenience's sake, the abbreviations Chla, DV-Chla and TChla were used for monovinylchlorophyll a, divinyl-chlorophyll a and the sum of these two pigments (total chlorophyll a) respectively. Concentrations of cyanobacteria phycoerythrin (PE) were assessed by spectrofluorometry both on the overall and $>10 \mu \mathrm{m}$ community, after extraction/cell resuspension in a 50/50 mixture of glycerol/phosphate buffer based on Wyman (1992). 1 to $3 \mathrm{~L}$ water samples were filtered through $47 \mathrm{~mm} 0.4 \mu \mathrm{m}$ polycarbonate membranes for total PE and 8L onto $10 \mu \mathrm{m}$ membranes for size-fractionated PE. Details of the PE spectrofluorometric analysis are given in Lantoine \& Neveux (1997), Neveux et al. (1999) and Neveux et al. (2006).

Picoplankton and nanoplankton analysis by flow cytometry. Subsamples $(1 \mathrm{~mL})$ were stored in cryovials, and fixed with paraformaldehyde (0.2\% final concentration, Campbell \& Vaulot 1993) and frozen in liquid nitrogen for a period of less than three months before flow cytometry analyses. Samples were counted on a Becton Dickinson FACSCan flow cytometer. For each cell,

185 forward and side light scattering as well as red and orange fluorescence were quantified. The light signals were calibrated using $1.002 \mu \mathrm{m}$ fluorescent beads (Polysciences Inc., Europe) as a reference. Four prevalent populations were distinguished and enumerated according to their scattering and florescence properties. Two of them belonged to picoplanktonic cyanobacteria, Prochlorococcus and Synechococcus, and two were eukaryotic groups, the smallest being deemed picoeukaryotes. Unicellular nanoplanktonic cyanobacteria such as Crocosphaera, easily recognized by the fluorescence excitation spectra of their phycoerythrin and by their flow cytometric signature (Neveux et al. 1999), were not observed during the Diapalis cruises.

193 Carbon biomass estimation. Information on the relative size of each population within the total 194 autotrophic biomass of the ecosystem was obtained by converting cell numbers into carbon units. 
Conversion factors $\left[\mathrm{fg} \mathrm{C} \mathrm{cell}{ }^{-1}\right]$ for Prochlorococcus (36), Synechococcus (255) and

196 picoeukaryotes (2590) were used according to Buitenhuis et al. (2012b) and for Richelia (10) from

197 Luo et al. (2012). For all filamentous cyanobacteria, the carbon conversion factor determined in 198 this study on Trichodesmium erythraeum was applied (17.22 ng C trichome ${ }^{-1}$; see Table 8). The integrated carbon content of each group and their relative percentages were calculated for the upper layer (0-60 m ST1 and ST2, 0-30 m at ST3). Note that diatoms and dinoflagellates in the $>10 \mu \mathrm{m}$ fraction were not included in the analysis, since mean cell size or cell volume was not determined.

\section{RESULTS}

205

206

\section{Environmental conditions during the 9 Diapalis cruises}

207

The New Caledonia region (Fig. 1) is typical of the tropical regime in the South West Tropical Pacific with clear-air temperature and precipitation seasonality (Fig. 2). The Diapalis period (2001-2003) coincided with the 2002-2003 El Nino build-up, with a first period (2001) marked by a Neutral Multivariate El Nino Index (MEI) and the second (2003) by a stronger positive MEI, indicative of a strong Central Pacific El Nino during D7-D9 (Fig. 2). On New

213 Caledonia's east coast, precipitations were more abundant during summer 2001-2002, with a 214 peak of cumulative rain in January-March 2002, while summer 2003 was drier, except for the 215 passage of Tropical Storm Beni, which crossed the area just before the February 2003 cruise. 216 Beni reached peak intensity on January 29 with winds of $125 \mathrm{mph}(205 \mathrm{~km} / \mathrm{h})$, before rapidly 217 weakening, and dissipating on February 5. It brought heavy precipitation and floods lasting 6 218 days.

219 During the austral summer, seawater temperature increased to $27^{\circ} \mathrm{C}$ at ST1 and ST2 and up to $28^{\circ} \mathrm{C}$ in the lagoon at ST3 (Fig. 3, left panel), leading to a vertical stratification and the formation of a pronounced thermocline (Fig. 4). During the winter, cooling of surface waters induced vertical mixing in the water column at least down to the deepest sampling level, e.g. 90$100 \mathrm{~m}$ in Aug 02 at ST2. Minimum temperatures in the upper layer were $23.4^{\circ} \mathrm{C}$ at ST1 and ST2 and $22.8^{\circ} \mathrm{C}$ at ST3. The highest salinities (around 35.4) were measured in Oct 03 at all three study sites, and the lowest during the wet summer season, in Apr 02 (from 34.47 at ST3, close to the mouth of the Ouinne River to 34.86 at ST1). Mean salinities were similar at ST1 and ST2 stations, 
227 but lower in summer 2002 than summer 2003, due to different precipitation regimes linked to the

228 El Nino episode (Fig. 2). Mean phosphate $\left(\mathrm{PO}_{4}^{-}\right)$concentrations in the upper layer (Fig. 3, right panel) were weak throughout the sampling period, reaching maximum values of 0.06-0.12 $\mu \mathrm{mol}$

$230 \mathrm{I}^{-1}$ in Oct 01 and Oct 03 during the transition periods and the minimum of $0.02 \mu \mathrm{mol} \mathrm{l}^{-1}$ in summer.

231 A small increase was observed in winter in Aug 02 due to a deepest MLD (Fig. 4). In wide Santal

232 Bay (ST1), $\mathrm{NO}_{\mathrm{x}}$ concentrations were also very low, except in Aug 02, when they reached 0.08

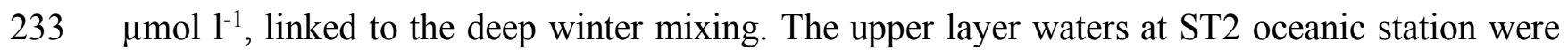

$234 \mathrm{NO}_{\mathrm{x}}$ poor with concentrations always $<0.06 \mu \mathrm{mol} \mathrm{l}^{-1}$ (Fig. 3), even during deep vertical winter

235 mixing as in Aug 02. Small maxima $\left(0.05 \mu \mathrm{mol} \mathrm{1}^{-1}\right)$ were observed in Oct 03 as in Feb 03 despite

236 warmer, saltier waters. At ST3 lagoon station, the $\mathrm{NO}_{\mathrm{x}}$ concentrations varied from 0.01 to a

237 maximum of $0.07 \mu \mathrm{mol} \mathrm{l}{ }^{-1}$ in Jan $02 . \mathrm{NH}_{4}{ }^{+}$concentrations (data not shown) at ST1 and ST2 were

238 generally low $<0.04 \mu \mathrm{mol}^{-1}$ and often close to the detection limit $0.01 \mu \mathrm{mol} \mathrm{l}^{-1}$. Higher

239 concentrations were observed only in Feb 03 at both stations $\left(0.11\right.$ and $0.19 \mu \mathrm{mol}^{-1}$ at ST1 and

240 ST2, respectively). In the lagoon, concentrations were on average slightly higher: up to $0.30 \mu \mathrm{mol}$ $2411^{-1}$.

\section{Filamentous cyanobacteria}

244 Specific composition: Five species of the Trichodesmium genus were observed (Fig. 5-6) and 245 identified by their morphology and morphometric characteristics (Table 2). Three of them, $T$. 246 erythraeum, T. thiebautii and T. tenue (Fig. 5A, B, H) were the most frequently observed at all 247 three sampling sites. T. contortum was seldom observed (3 samples). Katagnymene (Fig. 5E, F, 248 G) and Richelia/Calothrix (Fig. 6) genera were common (in $50 \%$ and $75 \%$ of samples, 249 respectively), but generally in low abundance. Richelia was observed as an endosymbiont of 250 Rhizosolenia and Hemiaulus and Calothrix as an epibiont on Chaetoceros sp. During the May 25102 cruise, west of Lifou, we observed unidentified filaments very similar to Trichodesmium, but differing in their very small cellular diameter $(2.7-3 \mu \mathrm{m})$. We also observed colonies of unidentified cyanobacteria (Fig. 5C, D), which formed clusters sometimes made up of several dozen cells. All filamentous species during Diapalis had dimensions (cell length and cell diameter) within the range published in the literature (Table 3 and 8) and the sizes of $T$. thiebautii and T. erythraeum species were in the low part of the size range.

257 Trichodesmium and Katagnymene abundance: At ST1 and ST2, the highest abundances of 258 filamentous cyanobacteria in the 0-60 m upper layer were noted in summer (Feb 03; Fig. 7), i.e. 
3000-4500 trichomes $1^{-1}$ and 1000-3000 trichomes $\mathrm{l}^{-1}$ between 5 and $10 \mathrm{~m}$, respectively. However,

260 the concentrations and vertical distribution could be highly variable from one day to another, as shown at ST1 in Feb 03 (Fig. 7). Some vertical profiles showed maximum concentrations at 40 $\mathrm{m}$ as at ST2 (mostly due to T. erythraeum). Vertical distributions were quite homogeneous at the period of low abundance, i.e. in the austral winter (Aug 02 and Jun 03). At ST3 (Fig. 7), concentrations did not exceed 1000 trichomes $1^{-1}$. Tables 4 to 6 give general statistics on the abundances of the different filamentous cyanobacteria enumerated by inverted microscopy during Diapalis cruises 1-9 for each station. Filamentous cyanobacteria were extremely rare in Oct 03 regardless of depth.

Assuming that Trichodesmium can migrate vertically within one day (Villareal \& Carpenter 2003), using integrated abundance seemed more appropriate for gauging their seasonal variations in the water column (Fig. 4). Thus, at ST2, 0-60 m integrated abundance showed a 500-fold variation between minimum in Oct $03\left(<0.510^{6}\right.$ trichomes $\left.\mathrm{m}^{-2}\right)$ during the transition periods and maximum in summer (Feb 03: $23510^{6}$ trichomes $\mathrm{m}^{-2}$ ). At ST1, the seasonal variations appeared similar but the variation range ( $\mathrm{x} 150)$ and the maximum summer concentrations $\left(7310^{6}\right.$ trichomes $\mathrm{m}^{-2}$ ) were lower than at ST2. At both stations, maximum abundance in summer 2003 was coincident with a shallow MLD, but low abundances were also observed in summer 2002 with a similar thermohaline structure. At ST3 station (Fig. 4), integrated concentrations (0-30 m only) were 15 times lower and varied from $0.910^{6}$ trichomes $\mathrm{m}^{-2}$ to $13.510^{6}$ trichomes $\mathrm{m}^{-2}$, although ST3 was not sampled in Feb 03.

The three main Trichodesmium species together accounted for $85-100 \%$ of the integrated biomass of filamentous cyanobacteria in terms of trichome numbers and always more than $51 \%$ in terms of trichome volume (Fig. 8). Trichodesmium tenue and T. thiebautii were generally the dominant species followed by $T$. erythraeum. Their mean cell numbers per trichome were relatively similar (Table 7). As expected, the percentage contribution of slender $T$. tenue was higher in terms of total trichome number than total volume (40-49\% vs $33 \%)$. Its percentage contribution (trichome numbers) was minimum at ST2 in Feb $03(23 \%)$ and maximum (>70\%) in Dec 01 at ST2 and ST3. T. thiebautii reached $>40 \%$ of the total trichome number in $65 \%$ of the samples with minimal contributions in Dec 01 and May 02 at ST2 $(<14 \%)$ and a fairly stable one at ST1 and ST3 (37-47 \%).

In terms of volumes, $T$. thiebautii contributions (reaches $50 \%$ at ST2) were more variable, linked to a trichome length changes along the annual cycle. The third main species, $T$. 
erythraeum, represented less than $18 \%$ of total trichomes on average, with the minimum contribution at ST3 $(<7 \%)$ and maximum at ST1 and ST2 in Feb 03 during the peak abundance (Tables 4 to 6). Its relative importance increased as expressed in volume, especially in Feb 03 at the two open ocean stations (22-28\%). T. contortum and T. hildebrandtii (given as "others" in Fig. 8), contributed $<3 \%$ to total trichome number or volume. The unidentified trichomes observed in May 02 further north than ST2 represented less than $1 \%$ of the integrated biomass.

The two Katagnymene species ( $K$. spiralis and $K$. pelagica) were not numerous, but their contribution in terms of volume was significant. Each form accounted for less than $4 \%$ of the total number of trichomes, except K. spiralis at ST1 in Oct $01(10 \%)$. K. spiralis was observed in $50 \%$ of samples. Its highest contributions to the total volume of trichomes occurred at ST1 in Oct $01(28 \%)$ and Feb 03 at ST2 (12\%). The contribution of $K$. pelagica was around $20 \%$ of the total volume in Feb 03 at ST1 and ST2, $15 \%$ at ST2 in Oct 01, and was not observed at ST3. The relative abundance of species could change along depth. For example, during cruises D4 and D5 (Apr-May 02), T. thiebautii and T. tenue were numerous in the upper layer (60\%) and disappeared at 50 meters while T. erythraeum peaked at this depth. Obviously, the relative abundance depends on the biomass criteria considered. For example, at ST2 in Apr 02, $T$. erythraeum contributions at 30 to $50 \mathrm{~m}$ decreased in terms of trichome number $(6 \%)$ but increased $(41 \%)$ in terms of total volume, because trichome size increased. The opposite trend was observed for T. thiebautii.

Richelia intracellularis/Calothrix rhizosolenia (RC) from DDAs and unidentified cyanobacteria abundance: $R C$ (Tables 4 to 6) were observed in $75 \%$ of samples, but their abundance was never very high. The highest $R C$ abundances were recorded in Feb 03 at both ST1 and ST2 (64 trichomes $1^{-1}$ and up to 735 trichomes $1^{-1}$, respectively), accounting for less than $1 \%$ of total Trichodesmium trichome surface area and volume. Conversely, at ST3, peak abundance was observed for $R$. intracellularis in Oct 01 (up to 117 trichomes $1^{-1}$ at the surface) equivalent to $4.3 \%$ of Trichodesmium trichome volume. In our samples, $R C$ in DDAs experienced a considerable variation in filament length $(10-88 \mu \mathrm{m})$ and cell diameter (vegetative cells 2-7 $\mu \mathrm{m}$; heterocyst 3-10 $\mu \mathrm{m})$ or trichomes per host cell (1-22). We also noted that in most cases, the host cell was almost empty. Apart from Richelia, other symbiotic coccoid-form cyanobacteria (not necessarily diazotrophs) were also observed in Climacodium sp. and Ornithocercus sp., though only in the New Caledonian lagoon. 
Colonies of unidentified cyanobacteria composed of round-shaped cells observed in some samples reached less than $1 \%$ of Trichodesmium biomass on average (Tables 4 to 6, Fig 5C, D). The highest concentrations were observed at ST2 during Jan 02 and May 02 with values exceeding 4000 cells $1^{-1}$, which was equivalent to less than $1.6 \%$ of Trichodesmium trichome volume. At ST1, these organisms were rarely observed and only at very low concentrations, i.e. $<20$ cells $1^{-1}$.

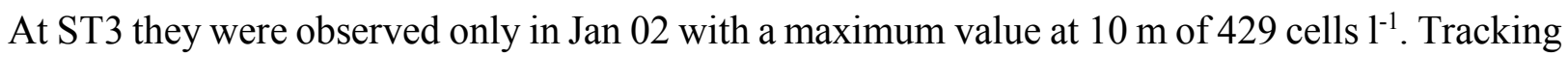
Crocosphaera (2-10 $\mu \mathrm{m}$ cell size) by flow cytometric and phycoerythrin signatures was unsuccessful during Diapalis although it has been reported in the region (Saito et al. 2010 and references therein). However, Diapalis samples showed relatively high $\mathrm{N}_{2}$ fixation in the $<10 \mu \mathrm{m}$ fraction, particularly in Oct 03 (Garcia et al. 2007), but it was not possible to link this fixation to specific organisms or biomass indicators.

\section{Abundance of other phytoplankton groups}

Picoplankton abundance: Prochlorococcus concentrations at ST1 and ST2 (Tables 4-5 and Fig. 9A) was maximum (10-13 10 ${ }^{12}$ cells $\mathrm{m}^{-2}$ ) during the warm season (Dec 01-Apr 02 and in Feb 03). During transition periods, concentrations were lower by a factor of 3 with 3.5-3.9 $10^{12}$ cells m ${ }^{-2}$ at ST2 (Oct 01 and Oct 03, respectively), while at ST1 the minimum concentration $\left(4.510^{12}\right.$ cells $\mathrm{m}^{-2}$ ) was observed during winter. At these two oceanic stations, the vertical distribution of Prochlorococcus was quite similar, with a marked maximum below the thermocline (40-80 $\mathrm{m})$ in summer and a more homogeneous distribution down to $60-80 \mathrm{~m}$ in winter. At ST3, Prochlorococcus abundance was much lower than at the oceanic stations, with values $<2.310^{12}$ cells $\mathrm{m}^{-2}$ through 0-30 m (max $7010^{3}$ cells $\left.\mathrm{ml}^{-1}\right)$, except in Dec 02 when they reached $4.810^{12}$

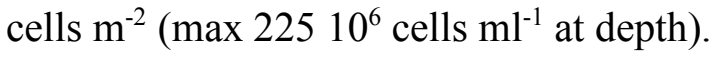

Unlike Prochlorococcus, integrated abundance of Synechococcus (Tables 4 to 6, Fig. 9B), was on average 5 to 14 times higher at the lagoon station (ST3) than offshore (ST1 and ST2), except during the austral winter (Aug 02) when they were $24 \%$ higher in oceanic waters at ST2 $\left(1.9110^{12}\right.$ cells $\left.\mathrm{m}^{-2}\right)$. This winter maximum was linked to thoroughly-mixed cool waters down to $>60 \mathrm{~m}$. The maximum Synechococcus abundance at the oceanic stations was generally located shallower than that of Prochlorococcus, i.e. in the upper mixed layer or at the top of the thermocline, except during the Oct 03 cruise when it peaked at the same depth (between 75 and $110 \mathrm{~m})$. 
Picoeukaryotes were the least abundant picoplankton organisms (Tables 4 to 6, Fig. 9C). Integrated abundances were more variable at ST2 (factor 6; 0.02 to $0.1210^{12}$ cells $\mathrm{m}^{-2}$ ) than at ST1 (0.07 to $0.1410^{12}$ cells $\left.\mathrm{m}^{-2}\right)$. At ST3, integrated abundances changed from 0.08 to $0.1710^{12}$ cells $\mathrm{m}^{-2}$. Picoeukaryote maxima were consistently found below the thermocline and, therefore, deeper than the Synechococcus maxima, even in Aug 02.

Large eukaryotes: Large eukaryotes $(>10 \mu \mathrm{m})$ described by microscopy and made up of dinoflagellates and diatoms (Fig. 10) were generally found together with Trichodesmium in open ocean waters at ST1 and ST2 and, to a lesser extent, at ST3 coastal site. Dinoflagellates showed a maximum of $6010^{6}$ cells $\mathrm{m}^{-2}$ during the maximum Trichodesmium abundance in Feb 03 at ST1 and ST2 and low abundance $\left(<3010^{6}\right.$ cells $\left.\mathrm{m}^{-2}\right)$ at other periods. Diatoms also showed a maximum concentration $\left(41210^{6}\right.$ cells $\left.\mathrm{m}^{-2}\right)$ in Feb 03 at ST2 and, to a lesser extent, at ST1. At ST3 coastal site, no data were available in Feb 03, but there was a considerable maximum for both groups (17 $10^{6}$ cells $\mathrm{m}^{-2}$ for dinoflagellates; $24010^{6}$ cells $\mathrm{m}^{-2}$ for diatoms) in winter (Aug 02). The main diatoms belonged to 1) the Navicula, Nitzschia and Pseudo-nitzschia genera at ST1, 2) the Chaetoceros, Navicula and Pseudo-Nitszchia genera at ST2, 3) the Chaetoceros, Navicula and Rhizosolenia genera at ST3. Rhizosolenia was the main $R C$ host. Among dinoflagellates, protoperidinians were represented at all stations, but few larger cells were found as Ceratium and Amphisiolena species at ST3 in Oct 01.

\section{Chlorophyll and phycoerythrin distribution}

Pigment content (Chla, PE) per cell or per trichome (Table 8) was calculated for Diapalis samples during the Feb 03 cruise at ST1 and ST2, and for a pure sample of T. erythraeum. Mean

377 Chla concentration per trichome was $99 \mathrm{pg} \mathrm{cell}^{-1}$ for pure T. erythraeum while the relationship between trichome numbers and Chla in the $>10 \mu \mathrm{m}$ fraction suggested an upper limit for the mean Chla concentration per trichome of $43 \mathrm{pg}$ for the mixed community of Trichodesmium (Table 8). Considering the diatoms and dinoflagellates in the $>10 \mu \mathrm{m}$ fraction revealed by microscopy and by the presence of a significant quantity of Chlc, the Chla per trichome would be approximately $10 \%$ lower (assuming a constant Chlc/Chla ratio of 0.2 for diatoms and dinoflagellates) than this upper limit. Similarly, the PE per trichome (Table 8) was $251 \mathrm{pg}$ trichome ${ }^{-1}$ for pure T. erythraeum and $197 \mathrm{pg}$ trichome $^{-1}$ for mixed Trichodesmium (Table 8). 
cyanobacteria according to Neveux et al. (2006) with either PE-Synechococcus or PETrichodesmium dominating or a clear mixture of both PEs. At ST1 and ST2 stations, PETrichodesmium dominated the community in Dec 02 and Feb 03. Integrated Total Chla change showed much less variation across cruises than trichome abundance (Fig. 11). The integrated proportion of Dv Chla to TChla was generally around $20 \%$ in lagoon waters (ST3), $40 \%$-50 \% at ST1 and over $50 \%$ in the Loyalty Channel (ST2). The highest integrated values of PE at ST1 and ST2 in Feb 03 (69 mg.m ${ }^{-2}$, Fig. 11) was linked to the high abundance of Trichodesmium at the surface while the high value in Oct 03 at ST1 was related to a deep maximum of Synechococcus. In Feb 03, PE maxima measured in the upper layer were 4 to $>10$ times higher than during the other cruises, ranging from $0.61 \mu \mathrm{g} \mathrm{1^{-1 }}$ at ST1 to $1.27 \mu \mathrm{g} \mathrm{l}^{-1}$ at ST2. In the $>10 \mu \mathrm{m}$ fraction, the PE in the upper layer (data not shown) was exclusively related to filamentous cyanobacteria, mainly Trichodesmium. At ST3 station (Fig. 11), PE was essentially related to Synechococcus and concentrations varied between 0.10 (Apr 02) and $0.62 \mu \mathrm{g} \mathrm{l}^{-1}$ (Aug 02) at the surface with fairly even vertical distribution. The integrated concentrations varied from 4.30 (Apr 02) to $29.26 \mathrm{mg} \mathrm{m}^{-2}$ (Aug 02). The integrated $\mathrm{N}_{2}$ fixation rate for all species (Garcia et al. 2007) roughly followed the integrated PE pattern (Fig. 11) and are correlated with the integrated trichome concentrations $\left(\mathrm{r}^{2}=0.73, \mathrm{~N}=11\right)$.

403

\section{C biomass distribution in the microbial community}

405 picoplankton and filamentous cyanobacteria (Fig. 12) was generally high at ST2 with maxima in summer ( $80 \%$ in Feb 03) and minima in winter (6\% in Aug 02), where TK was replaced by Synechococcus as the major contributor and in Oct 03 with only a few filaments observed. Comparatively, the contribution of TK at ST1 was lower, with a maximum of $\sim 50 \%$ in Feb 03. At ST3, Synechococcus was the main contributor to C biomass and the contribution of TK was generally low. At all stations, the contribution of $R C$ to $\mathrm{C}$ biomass was negligible over the whole sampling period. Picoeukaryotes may account for a significant portion of the biomass in the lagoon near Ouinne and in winter at all stations.

\section{Correlations between groups and environmental variables}


To determine the impact of environmental variables on the abundance variations of the different phytoplanktonic groups and species, Spearman correlations were calculated between integrated abundances of each filamentous species, integrated nutrients, and depth-averaged temperature and salinity, at each station/cruise (Table 9). Significant positive correlations were found between total trichome abundance, temperature and ammonium and a negative correlation with phosphate, but no significant correlation with MLD (see also Fig. 4). At the species level, $R C$ showed a strong positive correlation with MLD and ammonium, but $K$. pelagica only with phosphate, while $K$. spiralis was strongly correlated with all the analyzed nutrients $\left(\mathrm{NO}_{\mathrm{x}}\right.$, phosphate and ammonium). Diatom and picoplanktonic species did not show any correlation with environmental parameters. Inter-species correlations revealed that $R C$ was positively correlated with $T$. thiebautii and $K$. spiralis, but not with $T$. tenue (inversely correlated with $T$. thiebautii). Dinoflagellates were closely correlated with total trichome abundance and T. erythraeum, but inversely with $K$. pelagica. No correlations were evidenced between diatoms and the other groups. Finally, Synechococcus and picoeukaryotes showed a positive correlation.

\section{DISCUSSION}

\section{Influence of methodology on enumeration and biomass estimates}

As part of the effort of collecting biomass and metabolic rates specific to different phytoplankton functional groups, a database on diazotrophic organisms in the global pelagic upper ocean was built by Luo et al. (2012). Variability in counting and sampling procedures, however, hamper comparisons between studies around the world, especially for filamentous cyanobacteria. Significant error in the accuracy of low abundance measurements occurs depending on the sampling mode. In this case, the use of a plankton net increased the detection of Trichodesmium ( 0.1 against 1 trichome. $\left.1^{-1}\right)$ by a factor of 10 compared to water samples collected with 2.5 L GO FLO bottles (Chang et al. 2000). When bottle sampling, it is essential to filter all the contents to prevent uneven distribution of Trichodesmium, which can occur when trichomes (and colonies) migrate due to cell-controlled or uncontrolled buoyancy (Bergman et al. 2013). When tightly-packed filaments of T. erythraeum are observed at the surface, manual sampling within the first few millimeters of depth with narrow-necked plastic bottles provides a fairly accurate picture of trichome abundance, despite the somewhat uneven distribution. 
Abundance data are usually expressed as cell, trichome or colony numbers with or without specific information on the taxonomic composition of filamentous cyanobacteria. Conversion factors from one unit to another are, however, vague and based on the morphometric variability of filamentous diazotrophs (Luo et al. 2012), such as the number of trichomes per colony, cell numbers per trichome, and trichome dimensions, which are quite variable. For the Diapalis data set, trichome counts of mixed species were linearly correlated (Spearman's rank coefficient $>$ $0.95, \mathrm{p}<0.001)$ with the estimates of entire surface and total volume of trichomes, as previously pointed out by Neveux et al. (2006). So, replacing trichome numbers with trichome surface areas or volumes did not greatly modify the qualitative vertical distributions or seasonal trends in the filamentous biomass. This indicated a relatively constant composition of the filamentous community. Also, mean T. erythraeum carbon content per trichome (17.22 ng) and per cell (290 pg) were determined by our microscope counts. These values were in the upper range of the approximate cell carbon content previously published for Trichodesmium species assuming 100 cells trichome ${ }^{-1}$ (110-250 pg C cell ${ }^{-1}$; Luo et al. 2012). Taking the measured value of $290 \mathrm{pg} \mathrm{C}$ cell $^{-1}$ of T. erythraeum (Table 8 ), TK accounted for up to $80 \%$ of $\mathrm{C}$ cyanobacteria biomass in summer at the oceanic station of the Loyalty Channel, which confirms the essential role of filamentous cyanobacteria for the global food chain (Bergman et al. 2013) and in the south western tropical Pacific Ocean (SWTP) (Biegala et al. 2014, Bonnet et al. 2015).

\section{Comparison of Trichodesmium abundance with other studies}

During the Diapalis program, Trichodesmium spp. abundance in the ocean varied from 1 to 4578 trichomes $1^{-1}$ found at 0 to 60 meters (average 586 trichomes $1^{-1}, \mathrm{n}=88$ ), which was much higher than previously published data in New Caledonian waters at the end of the summer (2501000 trichomes $1^{-1}$ in April 1998; Campbell et al. 2005). The only other abundance data available for our region around New Caledonia are nifH gene copies (Moisander et al. 2010). In Ouinne lagoon, a maximum of 1200 trichomes $1^{-1}$ was found in summer 2007 and more than 10,000 trichomes $1^{-1}$ in accumulations (Rodier \& Leborgne 2010). These concentrations are, however, lower than measured in a surface accumulation in the Southwest Lagoon, namely up to $3010^{6}$ trichomes $1^{-1}$ for a Chla value of $3 \mathrm{mg} . \mathrm{l}^{-1}$ (Neveux et al. 2009), the highest values reported for the region. Such surface accumulations $\left(>10,000\right.$ trichomes $\left.1^{-1}\right)$ of mixed Trichodesmium species were collected 98 times in summer between New Caledonia and Vanuatu (1998 to 2010: Dupouy 
et al. 2011, 2017). In the southernmost part of the SWTP at $28^{\circ} \mathrm{S}$ in the austral summer, Law et

482

483

484

485

486

487

488

489

490

491

492

493

494

495

496

497

498

499

500

501

502

503

504

505

506

507

508

509

510

511 al. (2011) observed comparatively low surface Trichodesmium abundance, averaging 11 trichomes $1^{-1}$ in the upper $10 \mathrm{~m}$ to 6 trichomes $1^{-1}$ at $35-50 \mathrm{~m}$. Some high values were found in the Solomons Islands, expressed as trichome number (7700 trichomes $1^{-1}$; Giraud et al. 2016) or NifH copies (Bonnet et al. 2015). In the Western North Pacific Ocean, abundance was between 1 and 400 trichomes $1^{-1}$ (Marumo \& Asaoka 1974, Marumo \& Nagasawa 1976, Chen et al. 2003, Shiozaki et al. 2015) with some high values in accumulations $\left(>20,000\right.$ filaments $\left.1^{-1}\right)$ near the Miyako Islands (Shiozaki et al. 2015).

Comparing the Diapalis program with other time series conducted on Trichodesmium in subtropical waters raises a number of problems, as a different sampling strategy and sample processing method were used. During the Hawaiian (HOT) and Bermuda Atlantic Time-Series (BATS), Trichodesmium abundance was studied at approximately monthly intervals (HOT= October 1989-December 1992, Letelier \& Karl 1996; BATS = 1995-1997, Orcutt et al. 2001) and free trichomes (water filtration sampling) and colonies (net sampling) were counted separately. So, a conversion factor of 200 trichomes per colony used in Orcutt et al. (2001) was applied to HOT and BATS counting data for comparisons with the Diapalis values, as in our study colonies were not counted (disintegrated during the counting) and only trichome abundance is available. This showed that trichome abundances in New Caledonian waters were generally higher than those observed at HOT and BATS stations. In fact, the integrated maxima observed in Feb 03 in the Loyalty Channel (240 $10^{6}$ trichome $\mathrm{m}^{-2}$ ) were 70 times and 400 times higher than at HOT (3.5 $10^{6}$ trichome $\left.\mathrm{m}^{-2}\right)$ and BATS $\left(0.6410^{6}\right.$ trichome $\left.\mathrm{m}^{-2}\right)$, respectively. Moreover, mean cell numbers per trichome were generally lower in Diapalis samples (50-60) than at HOT (100). At HOT, apical cells were counted and divided by two to obtain the trichome number (Letelier \& Karl 1996). This precaution was not applied to Diapalis samples, leading to a possible overestimation of trichome numbers due to trichome breaking during sample processing. HOT and BATS studies have shown a maximum abundance in summer and relatively strong inter-annual variability, even if free trichome variations at BATS seemed identical from one year to another. At BATS, however, interannual variations deduced from only 7 integrated depth profiles for 3 years fitted by a thirddegree polynomial function of Julian days (Fig 1A in Orcutt et al. 2001), are questionable.

Filamentous diazotroph species and their relationship with environmental factors 
513 (LNLC) region (Ceccarelli et al. 2013), with phosphate recharged annually (presumably other

514 nutrients as well) in the euphotic zone during the transition periods (Moutin et al. 2005). The

515 phosphate can limit the growth of diazotrophs species and consequently controls nitrogen

516 fixation rates in the ocean (Karl et al. 2002). In LNLC, diazotroph species such as

517 Trichodesmium are better adapted as they are able to use atmospheric $\mathrm{N}_{2}$ (Bergman et al. 2013).

518 Diazotrophs are likely responsible for the lower phosphate concentrations in summer in the

519 region due to their $\mathrm{PO}_{4}$ uptake (Moutin et al. 2005, Shiozaki et al. 2014), which corroborates the

520 negative correlation between Trichodesmium and phosphate found in this study. During

521 Diapalis cruises the ammonium concentrations at ocean stations were only high in February

5222003 coinciding with the highest concentrations of trichomes, PE and cyanobacteria carbon. The

523 ammonium concentrations also were positively correlated to Trichodesmium densities.

524 Therefore, the relatively high ammonium concentrations may be attributed partially to direct or

525 indirect release of this nutrient by the diazotrophs (Mulholland 2007; Bergman et al. 2013). We

526 did not find any correlation between Trichodesmium abundance and MLD. As stated by Hood et

527 al. (2004), increased Trichodesmium concentrations are linked to a shallow MLD (resulting in

528 high mean light levels) and low dissolved inorganic nitrogen (DIN) concentrations for extended

529 periods of time. The relationship between nitrogen fixation rates in plankton net samples and

530 MLD depth was significantly fitted by a hyperbolic function in the Atlantic Ocean $\left(\mathrm{r}^{2}=0.31, \mathrm{p}\right.$

$531<0.05, \mathrm{n}=18$, Agawin et al. 2013).

$532 T$. thiebautii and T. tenue were the predominant species in the oceanic waters around New

533 Caledonia and in the open lagoon of the east coast, as previously stated in Rodier \& Leborgne

534 (2010). By contrast and according to these authors, T. erythraeum dominate in the SW lagoon of

535 New Caledonia, which is a semi-closed and larger lagoon than the SE lagoon. Generally, $T$.

536 thiebautii and T. tenue are poorly represented in coastal regions (Relevante \& Gilmartin 1982).

537 They dominate in the oligotrophic gyre of the Northern Pacific, Western Pacific (Marumo \&

538 Nagasawa 1976) and eastern part of the China Sea (Marumo \& Asaoka 1974) and are likely better

539 adapted to low-nutrient conditions than T. erythraeum. In our study, T. tenue was inversely

540 correlated with $T$. thiebautii, which suggests competition between the two species for an

541 apparently similar environment. According to Romans et al. (1994), T. tenue is a common species

542 often confused with $T$. thiebautii in optical microscopy, which can explain the lack of information

543 on the species' distribution and quantification. The predominance of $T$. tenue observed on 
544 occasion during the Diapalis cruises is a relatively original finding. In this study around New

545 Caledonia, T. contortum and T. hildebrandtii occur in very low densities as in most oceans 546 (Bergman et al. 2013).

547 Information on Katagnymene species in the field is very scarce. They are mentioned in the 548 Southwestern Pacific (Lundgren et al. 2001, Dupouy et al. 2011, Giraud et al. 2016). Both 549 Katagnymene species, $K$. pelagica and $K$. spiralis, should now be considered as two 550 morphological forms of the same species (Lundgren et al. 2005). In our study, both forms are 551 frequently observed, but always in low abundance $<284$ trichomes $1^{-1}$. The strongest 552 concentrations were observed in the first 40 meters, although a deeper maximum $(60 \mathrm{~m})$ was 553 found in the Loyalty Channel in Feb 03. At this maximum, the K. spiralis form accounts for 81 $554 \%$ of the Katagnymene genus. Along the Revelle cruise track between New Caledonia and the Fiji 555 Islands (April 1998), Lundgren et al. (2001) found both Katagnymene forms at 34 of the 51 stations and counted up to 400 trichomes $1^{-1}$ of Katagnymene in the 0-25 m layer, with $89 \% \mathrm{~K}$. pelagica. It should be noted that Katagnymene trichomes are generally long $(1 \mathrm{~cm})$ and extremely fragile and can be broken up by handling before counting; hence the recommended use here of surface and total volume for biomass estimates. The significant relationship of $K$. spiralis with all nutrients, while $K$. pelagica was correlated only with phosphate, may indicate a different ecological niche for these two species.

Like Trichodesmium and Katagnymene, the heterocystous Richelia intracellularis is widespread in warm tropical and subtropical waters (Luo et al. 2012, Bonnet et al. 2015), whereas Calothrix rhizosolenia, as epibionts of Chaetoceros, have been observed in the Indian and Western Pacific Oceans (Sarma 2012, Giraud et al. 2016). Around New Caledonia in this study, both Richelia and Calothrix species ( $R C$ groups) were sometimes present as free-living organisms, but more frequently in endosymbiotic association with diatoms (mainly in Rhizosolenia sp.). $R C$ were present in all seasons with a maximum $\left(>700\right.$ trichomes $\left.1^{-1}\right)$ in the Loyalty Channel in summer (Feb 03), as was Trichodesmium. Based only on samples where $R C$ was detected, its biomass correlated with the number of diatoms in the $>10 \mu \mathrm{m}$ fraction (Spearman rank correlation between 0.52 and $0.57, \mathrm{p}<0.0001$; data not shown). In endosymbiosis, the host cell provides a protective micro-environment and positive buoyancy to the symbiont, which enables the cell to remain in the euphotic layer, as, unlike Trichodesmium, this species does not have gas vacuoles (Janson et al. 1999). Richelia has a very uneven space distribution in the oceans, like Trichodesmium, depending on whether the environment is conducive to their growth. Both 
genera often inhabit the same types of ecosystems, as they have similar physiological properties, like all diazotrophs (Bergman et al. 2013 and references therein). In the case of cyanobacteriadiatom associations, environmental conditions must meet the needs of both organisms, and particularly sufficient silicate concentration for the diatom host growth. Iron and silica were not limiting factors in our area of study and are provided by leaching from terrestrial soils (Shiozaki et al. 2014). In our study, $R C$ was more correlated with $T$. thiebautii and $K$. spiralis, and its positive dependence on the density structure of the water column (MLD) and ammonium needs to be further explored. In the Northern Pacific Gyre, the greatest abundance in Richelia intracellularis is also observed in summer, when the species can form blooms of about $10^{4}$ filaments per liter (Venrick 1974), values which are thus greater than ours (max 734 filaments 1${ }^{1}$ ). Around the Hawaiian Islands (Sohm et al. 2011), a high abundance of all three groups, i.e. and summer 2003 (July-Aug), with Richelia-diatom associations more abundant to the south of the islands. The high variability in Richelia size in our samples is another reason to underline the inaccuracy of biomass measurements in terms of filament numbers rather than total filament surface area or volume. The contribution of $R C$ in terms of volume (or carbon) was minor $(<1 \%)$ but must not mask the great impact of this species on carbon sequestration by DDA's as shown in the North Tropical Pacific (Dore et al. 2008, Karl 2014; Karl \& Church 2014).

In our study, large diatoms did not show significant correlations with any of the other groups enumerated nor with any of the environmental variables. Dinoflagellates correlated positively with total trichome abundance. Their positive correlation with the percentage of T. erythraeum and their negative correlation with the percentage of $K$. pelagica, suggested affiliation to more coastal than oceanic environments. The diversity of trophic status in dinoflagellates (photosynthetic, mixotroph, heterotroph) was, nevertheless, not considered in the analysis. In the

600 Northern Tropical Pacific, the dinoflagellate group revealed no specific ecological pattern nor any characteristic assemblages (Giraud et al. 2016). During the Diapalis cruises, the picoplanktonic groups did not show any correlation with environmental parameters (Table 9), which was surprising, as Synechococcus and Prochlorococcus have distinct ecophysiology, Synechococcus 604 being better adapted to mesotrophic conditions and Prochlorococcus to oligotrophic conditions 605 (Partensky et al. 1996). This could be explained for Prochlorococcus by the fact that their 606 abundance varied little over the annual cycles. Prochlorococcus never dominated the phytoplankton $\mathrm{C}$ biomass, but were often the second contributor to $\mathrm{C}$ biomass after filamentous 
cyanobacteria in oceanic waters (Fig. 12). All phytoplankton share a requirement for light and nutrients. A more specific mechanism underlying the covariation between Synechococcus and the picoeukaryotes, as opposed to Prochlorococcus, is that they have a larger cell size than the latter, and are able to use nitrate. This could explain they tend to respond positively to enhanced nutrient supply as observed mostly in the lagoon station and at Santal Bay. The covariation between

613 Synechococcus and the picoeukaryotes has been described before in the Atlantic subtropical gyres 614 (Marañón et al. 2003) and in the Pacific Ocean (Worden et al. 2004). The significant positive correlation between Synechococcus and picoeukaryotes may also occur due to similarities in 616 favorable light conditions (Gutiérrez-Rodríguez et al. 2016). Synechococcus and picoeukaryotes dominated the $\mathrm{C}$ biomass in the lagoon, but may also be large contributors in oceanic waters, as observed in winter (Fig. 12).

619

\section{1-2003 Inter-annual variability}

The difference in large diazotroph abundance (and nitrogen fixation rates, Garcia et al. 2007; Fig. 12C) observed between the summers of 2001-2002 and 2002-2003 could be the result of a relatively low in situ sampling frequency. Satellite imagery nevertheless confirmed the very low chlorophyll values during summer 2001-2002 compared to summer 2003 (Dupouy et al. 2011). Moreover, satellite-classified Trichodesmium pixels in the region $5^{\circ} \mathrm{S}-25^{\circ} \mathrm{S}, 160^{\circ} \mathrm{E}-170^{\circ} \mathrm{W}$ determined using the TRICHOSAT model were clearly lower in summer 2001-2002 (La Niña years) than summer 2003 (an El Niño year). The spectral fluorescence signature of surface blooms as measured by the MERIS sensor (Gower et al. 2014) was also high during El Niño summers (2003, 2007, 2010) but low during La Niña summers. The difference in cumulative precipitation between 2001-2002 and 2003 summers is striking, with 2003 being drier despite the occurrence of two tropical storms, namely Beni in January 2003 and Erica in March 2003 (Neveux et al. 2009). Law et al. (2011) reported that nitrogen fixation increased owing to an iron supply from a wet-dust deposition 8 days after Tropical Cyclone Wati in the Tasman Sea. Australian dust peaking in 2001 and 2002 was cited as a potential factor in increasing occurrence in the seas to the east of Australia (estimated by satellite) in 2001-2005 (Mackie et al. 2008). The regional distribution of aerosols was probably also influenced by the continuous passive (non-explosive) volcanic degassing of the Melanesian Volcanic Arc, as indicated by sulfur dioxide $\left(\mathrm{SO}_{2}\right)$, the composition of which has been analyzed using satellite data and modelling (Lefèvre et al. 2015). 
640 Likewise, Sahara dust deposition at BATS corresponded to an increased abundance of

641 Trichodesmium colonies as well as changes in their chemical composition, even though it did not

642 enhance the $\mathrm{N}_{2}$ fixation rate per colony (Orcutt et al. 2001). At BATS, inter-annual variability

643 could also be related to the relative extent of vertical mixing from one year to another, including

644 the effects of hurricane frequency, which would reduce Trichodesmium abundance (Orcutt et al.

645 2001). During the Diapalis program, this negative vertical-mixing effect was not confirmed, as

646 the highest Trichodesmium abundance occurred just after Tropical Storm Beni struck New

647 Caledonia in Late January 2003. Inter-annual variability would also have been related to changes

648 in main-current transports, i.e. a westward Sverdrup transport and trade winds enhanced during

649 El Niño periods as against falling Sverdrup transport and strengthening northwesterly winds 650 during La Niña (Kessler \& Cravatte 2013; Cravatte et al. 2015). Wind regime, which may impact 651 mixed-layer formation is known to alternate around New Caledonia with a trade-wind regime 652 during El Niño and more westerly winds during La Niña, which may increase surface currents in 653 the Loyalty Channel (Lefèvre et al. 2010). How such large-scale current variability or atmospheric 654 composition influence total biomass and Trichodesmium abundance in New Caledonia is not clear 655 yet.

\section{CONCLUSION}

659 In 2001-2003, the seasonal and inter-annual variations in cyanobacteria abundance were 660 investigated in New Caledonian waters during the 9 Diapalis program cruises. Three sites 661 representative of different biotopes were sampled, i.e. open ocean (Loyalty Channel), coastal 662 (lagoon off the Ouinne River estuary) and deep bays (Santal Bay at Lifou). Abundance was 663 determined at the species level for diazotrophic filamentous cyanobacteria. Our description of the 664 organisms ( $R C$ and diatoms) in symbiotic associations was well detailed. Filamentous 665 cyanobacteria were practically always present throughout the year, but with relatively high 666 variations. The highest abundances occurred during the summer seasons. The dominant species 667 were Trichodesmium thiebautii and T. tenue, followed by T. erythraeum. Katagnymene as well as 668 Richelia species (mainly endosymbiotic in diatoms), which were consistently present in low 669 abundance. Microscopic examination also revealed the presence of unknown filamentous species 670 formed by round-shape cells not yet described by molecular tools. Picoplanktonic cyanobacteria 671 (Prochlorococcus and Synechococcus) were consistently present in abundance with less 
672 pronounced seasonal variations than filamentous cyanobacteria. Trichodesmium dominated in

673 terms of carbon content in the Loyalty Channel and Santal Bay in summer, while Synechococcus 674 dominated at the Ouinne station and in winter at all the three stations. The comparison of the 2002 675 and 2003 summers showed major inter-annual variability. Environmental factors that could 676 explain this variability were not clearly identified. One hypothesis could be the effects of 677 alternation between La Niña and El Niño with maximum diazotrophs and Trichodesmium 678 abundance during a well-established El Niño. Some hypotheses relating to the El Niño/La Niña 679 cycle need verifying, i.e. dust inputs and links with precipitations, winds, vertical movements and 680 horizontal circulation within the upper 200-meter layer, gyre formation in relation to wind 681 strength and direction and increased mesoscale circulation.

Acknowledgements. Abundance and pigment data were acquired during 9 cruises between 2001 and 2003 under the DIAPAZON (DIAzotrophie PAcific ZONe) research program on the biogeochemical environment of filamentous abundance and diazotrophy in the waters of the New Caledonian island group. We are grateful to Aubert Le Bouteiller, head of the DIAPAZON program, IRD, INSU PROOF (Programme national étude des PROcessus biogéochimiques dans l'Océan et Flux). The authors also wish to acknowledge the captains and crews of the R/V IRD Alis as well as everyone who took part in the nine cruises. We are indebted to Meteorologie Nationale for precipitation and air temperature data on Thio-Plateau. Special thanks go to Philippe

691 Gérard for nutrient analyses and LAMA (US IMAGO). Our sincere gratitude also goes to the IRD 692 Noumea Center administrative staff for their support throughout this three year program.

\section{LITERATURE CITED}

695 Agawin, NSR, Tovar-Sanchez A, Knoth De Zarruk K, Duarte CM, Agusti S (2013) Variability 696 in the abundance of Trichodesmium and nitrogen fixation activities in the subtropical NE 697 Atlantic. J Plankt Res 35(5):1126-1140

698 Bergman B, Sandh G, Lin S, Larsson J, Carpenter EJ (2013) Trichodesmium - a widespread 699 marine cyanobacterium with unusual nitrogen fixation properties. FEMS Microbiol Rev $700 \quad 37: 286-302$

701 Biegala IC, Raimbault P (2008) High abundance of diazotrophic picocyanobacteria $(<3 \mu \mathrm{m})$ in a 702 Southwest Pacific coral lagoon. Aquat Microb Ecol 51(1):45-53 
Biegala IC, Aucan J, Desnues A, Rodier M, Dupouy C and others (2014) The South Pacific Ocean Time Series (SPOT) station: a first focus on diazotrophs community. http://www.eposters.net/poster/the-south-pacific-ocean-time-series-spot-station-a-first-focuson-diazotrophs-community

Bonnet S, Rodier M, Turk K, Germineaud C and others (2015) Contrasted geographical distribution of N2 fixation rates and nifH phylotypes in the Coral and Solomon Seas (SouthWestern Pacific) during austral winter conditions. Global Biogeochem Cycles 29:1874-1892, doi:10.1002/(2015) GB005117

Bonnet S, Moutin T, Rodier M, Grisoni J-M and others (2016) Introduction to the project VAHINE: VAriability of vertical and tropHIc transfer of diazotroph derived $\mathrm{N}$ in the southwEst Pacific. Biogeosciences 13: 2803-2814

Buitenhuis ET, Vogt M, Moriart R, Bednarsek N and others (2012a) MAREDAT: Towards a world ocean atlas of marine ecosystem data, Earth Syst. Sci. Data Discuss. 5:1077-1106, doi:10.5194/essdd-5-1077-2012

Buitenhuis ET, Li WKW, Vaulot D, Lomas MW and others (2012b) Picophytoplankton biomass distribution in the global ocean. Earth System Science Data 4:37-46, doi: 10.5194/essd-4-37-2012

Campbell L, Vaulot D (1993) Photosynthetic picoplankton community structure in the Subtropical North Pacific Ocean near Hawaii (Stat. Aloha). Deep-Sea Res 40(10):2043-2060

Campbell L, Carpenter EJ, Montoya JP, Kustka AB, Capone DG (2005) Picoplankton community structure within and outside a Trichodesmium bloom in the Southwestern Pacific Ocean. Vie Milieu 55 (3-4):185-195

Capone DG, Zehr JP, Paerl HW, Bergman B, Carpenter EJ (1997) Trichodesmium a globally significant marine cyanobacterium. Science 276:1221-1229

Ceccarelli DM, McKinnon AD, Andréfouët S, Allain V and others (2013) The Coral Sea: Physical Environment Ecosystem Status and Biodiversity Assets. Adv Mar Biol 66:213-290 ISBN: 978-0-12-408096-64

Chang J, Chiang KP, Gong GC (2000) Seasonal variation and cross-shelf distribution of the nitrogen-fixing cyanobacterium Trichodesmium in Southern East China Sea. Cont Shelf Res 20:479-492 
Chen YL, Chen H, Lin Y (2003) Distribution and downward flux of Trichodesmium in the South China Sea as influenced by the transport from the Kuroshio current. Mar Ecol Progress Ser 259:47-57

Cravatte S, Kestenare E, Eldin G, Ganachaud A, Lefèvre J, Marin F, Menkes C, Aucan J (2015) Regional circulation around New Caledonia from two decades of observations. J Marine Syst $148: 249-271$

Cronberg G, Carpenter EJ, Carmichael WW (2004) Taxonomy of harmful cyanobacteria. In: Hallegraeff CM, Anderson DM, Cembella AD (eds) Manual on harmful marine microalgae. UNESCO, Paris, p 523-562

De Boissieu F, Menkes C, Dupouy C, Rodier M, Bonnet S, Mangeas M, Frouin R (2014) Phytoplankton global mapping from space with a Support Vector Machine algorithm. Proc of SPIE $926192611 \mathrm{R}$

Dore JE, Letelier RM, Church MJ, Lukas R, Karl DM (2008) Summer phytoplankton blooms in the oligotrophic North Pacific Subtropical Gyre: Historical perspectives and recent observations. Prog Oceanogr 76:2-38

Dupouy C, Benielli-Gary D, Neveux J, Dandonneau Y, Westberry T (2011) A new algorithm for detecting Trichodesmium surface blooms in the South Western Tropical Pacific. Biogeosciences 8:1-17

Dupouy C, Rodier M, Rousset G, Dirberg, G (2017) Satellite detection of Trichodesmium blooms in the Southwest Pacific. Harmful Algae News, IOC, ISSHA, 57:9-10

Dutkiewicz S, Morris JJ, Follows MJ, Scott JR, Levitan O, Dyhrman S, Berman-Frank I, (2015) Impact of ocean acidification on future phytoplankton communities. Nat Clim Change 5(11):1002-1006, doi:10.1038/nclimate2722

Foster RA, Goebel NL, Zehr JP (2010) Isolation of Calothrix rhizosoleniae strain SC01 from Chaetoceros (BACILLARIOPHYTA) spp. diatoms of the subtropical North Pacific Ocean. J Phycol 46:1028-1037

Garcia N, Raimbault P, Sandroni V (2007) Seasonal nitrogen fixation and primary production in the Southwest Pacific: nanoplankton diazotrophy and transfer of nitrogen to picoplankton organisms. Mar Ecol Prog Ser 343:25-33

Giraud M, Gregori G, Barani A, Arakawa H (2016) A study of microphytoplankton and cyanobacteria consortia in four oligotrophic regimes in the western part of the North Pacific subtropical gyre and in the warm pool. J Plankt Res 38(5):1317-1333 
Gómez F, Furuya K, Takeda S (2005) Distribution of the cyanobacterium Richelia intracellularis as an epiphyte of the diatom Chaetoceros compressus in the Western Pacific Ocean. J Plankton Res 27(4):323-330

Gower J, King S, Young E (2014) Global remote sensing of Trichodesmium. Int J Rem Sens 35:5459-5466

Gruber N (2016) Elusive marine nitrogen fixation. PNAS 113(16):4246-4248

Gutiérrez-Rodríguez A, Selph KE, Landry MR (2016) Phytoplankton growth and microzooplankton grazing dynamics across vertical environmental gradients determined by transplant in situ dilution experiments, J Plankton Res 38(2): 271-289

Holmes RM, Aminot A, Kerouel R, Hooker BA, Petersen BJ (1999) A simple and precise method for measuring ammonium in marine and freshwater ecosystems. Canad J of Fish Aqu Sci 56:1801-1808

Hood RR, Coles VJ, Capone DG (2004) Modeling the distribution of Trichodesmium and nitrogen fixation in the Atlantic Ocean. J Geophys Res 109, C06006, doi:10.1029/2002JC001753

Ishizaka J, Kiyosawa H, Ishida K, Ishikawa K, Takahashi M (1994) Meridional distribution and carbon biomass of autotrophic picoplankton in the Central North Pacific Ocean during late northern summer 1990. Deep-Sea Res I (41):1745-1766

Jabir T, Dhanya V, Jesmi Y, Prabhakaran MP, Saravanane N, Gupta GVM, Hatha AAM (2013) Occurrence and Distribution of a Diatom-Diazotrophic Cyanobacteria Association during a Trichodesmium Bloom in the Southeastern Arabian Sea. International Journal of Oceanography, 2013:1-6, doi:10.1155/2013/350594

Janson S, Wouters B, Bergman B, Carpenter EJ (1999) Host specificity in the Richelia-diatom symbiosis revealed by hetR gene sequence analysis. Environ Microbiol 1(5):431-438

Karl DM, Michaels A, Bergman B, Capone DG and others (2002) Dinitrogen fixation in the world's oceans. Biogeochemistry 57/58:47-98

Karl DM, Church MJ (2014) Microbial oceanography and the Hawaii Ocean Time-series programme. Nat Rev Microbiol 12:699-713

Karl DM (2014) The contemporary challenge of the sea: Science society and sustainability. Oceanography 27(2):208-225

Kessler WS, Cravatte S (2013) ENSO and Short-Term Variability of the South Equatorial Current Entering the Coral Sea. J. Physical Oceanography 43:956-969 
Lantoine F, Neveux J (1997) Spatial and seasonal variations in abundance and spectral characteristics of phycoerythrins in the Tropical Northeastern Atlantic Ocean. Deep-Sea Res I 44 (2):223-246

Law CS, Woodward EMS, Ellwood MJ, Marriner AS, Bury J, Safi KA (2011) Response of surface nutrient inventories and nitrogen fixation to a tropical cyclone in the southwest Pacific. Limnol Oceanogr 56(4):1372-1385

Le Bouteiller A, Blanchot J, Rodier M (1992) Size distributions patterns of phytoplankton in the western Pacific: Towards a generalization for the tropical open ocean. Deep-Sea Res A 39:805-823

Lefèvre J, Marchesiello P, Jourdain N, Menkes C, Leroy A (2010) Weather regimes and orographic circulation around New Caledonia. Marine Poll Bull 61:413-431

Lefèvre J, Menkes C, Bani P, Marchesiello P, Cursi G, Grell GA, Frouin R (2015) Distribution of sulfur aerosol precursors in the SPCZ released by continuous volcanic degassing at Ambrym, Vanuatu. J. Volcanol. Geotherm. Res. 322:76-104, doi.org/10.1016/j.jvolgeores.2015.07.018

Letelier RM, Karl DM (1996) Role of Trichodesmium spp, in the productivity of the Subtropical North Pacific Ocean. Mar Ecol Prog Ser 133(1-3):263-273
Lugomela C, Lyimo TJ, Bryceson I, Semesi AK, Bergman B (2002) Trichodesmium in coastal waters of Tanzania: diversity, seasonality, nitrogen and carbon fixation. Hydrobiologia 477:1-13

Lundgren P, Soederbaeck E, Singer A, Carpenter EJ, Bergman B (2001) Katagnymene: Characterization of a novel marine diazotroph. J Phycol 37(6):1052-1062

Lundgren P, Janson S, Jonasson S, Singer A, Bergman B (2005) Unveiling of novel radiations within Trichodesmium cluster by hetR gene sequence analysis. Appl Environ Microbiol 71(1):190-196

Luo Y-W, Doney SC, Anderson LA, Benavides M and others (2012) Database of diazotrophs in global ocean: abundance biomass and nitrogen fixation rates. ESSD 4:47-73

Mackie DS, Boyd PW, McTainsh, GH, Tindale NW, Westberry TK, Hunter KA (2008)

Biogeochemistry of iron in Australian dust: From eolian uplift to marine uptake. Geochem Geophys Geosyst 9, Q03Q08: doi: 10.1029/2007GC001813 
Marañón E, Behrenfeld MJ, González N, Mouriño B, Zubkov MV (2003) High variability of primary production in oligotrophic waters of the Atlantic Ocean: uncoupling from phytoplankton biomass and size structure. Mar Ecol Prog Ser 257: 1-11

Marumo R, Asaoka O (1974) Trichodesmium in the East China Sea, 1, Distribution of Trichodesmium thiebautii Gomont during 1961-1967. J Oceanogr Soc Japan 30:298-303

Marumo R, Nagasawa S (1976) Seasonal variation of the standing crop of a pelagic blue green alga Trichodesmium in the Kuroshio Water. Bull Plankton Soc Japan 23:19-25

Masotti I, Ruiz-Pino D, Le Bouteiller A (2007) Photosynthetic characteristics of Trichodesmium in the southwest Pacific Ocean: importance and significance. Mar Ecol Prog Ser 338:47-59

McKinna L (2015) Three decades of ocean-color remote-sensing Trichodesmium spp. in the World's oceans: A review. Progr Oceanography 131:177-199

Moisander PH, Beinart RA, Hewson I, White AE, Johnson KS, Carlson CA, Montoya JP, Zehr JP (2010) Unicellular cyanobacterial distributions broaden the oceanic $\mathrm{N}_{2}$ fixation domain. Science 327(5972):1512-1514

Momper LM, Reese BK, Carvalho G, Lee P, Webb EA (2015) A novel cohabitation between two diazotrophic cyanobacteria in the oligotrophic ocean. The ISME Journal 9:882-893

Montegut CB, Madec G, Fischer AS., Lazar A, Ludicone D (2004) Mixed layer depth over the global ocean: An examination of profile data and a profile-based climatology. J.G.R. Oceans, doi:10.1029/2004JC002378

Moutin T, Van Den Broeck N, Beker B, Dupouy C, Rimmelin P, Le Bouteiller A (2005) Phosphate availability controls Trichodesmium spp, biomass in the SW Pacific Ocean. Mar Ecol Prog Ser 297:15-21

Mulholland, MR (2007) The fate of nitrogen fixed by diazotrophs in the ocean. Biogeosciences $4: 37-51$

Neveux J, Lantoine F (1993) Spectrofluorometric assay of chlorophylls and phaeopigments using the least squares approximation technique. Deep-Sea Res I 40(9):1747-1765

Neveux J, Lantoine F, Vaulot D, Marie D, Blanchot J (1999) Phycoerythrins in the Southern Tropical and Equatorial Pacific Ocean: Evidence for new cyanobacterial types. J Geophys Res 104(C2):3311-3321

Neveux J, Tenório MMB, Dupouy C, Villareal TA (2006) Spectral diversity of phycoerythrins and diazotrophs abundance in tropical South Pacific. Limnol Oceanogr 51(4):1689-1698 
Neveux J, Tenório MMB, Jacquet S, Torréton J-P, Douillet P, Ouillon S, Dupouy C (2009) Chlorophylls and Phycoerythrins as Markers of Environmental Forcings Including Cyclone Erica Effect (March 2003) on phytoplankton in the Southwest Lagoon of New Caledonia and Oceanic Adjacent Area. Int J of Oceanography, 232513, 19

Orcutt K, Lipschultz F, Gundersen K, Arimoto R, Michaels AF, Knap AH, Gallon JR (2001) A seasonal study of the significance of $\mathrm{N}$ fixation by Trichodesmium spp. at the Bermuda Atlantic Time-series Study (BATS) site. Deep-Sea Research II 48:1583-1608

Partensky F., Blanchot J., Lantoine F. Neveux J, Marie D. (1996) Vertical structure of picophytoplankton at different trophic sites of the tropical northeastern Atlantic Ocean. Deep-Sea Res I 43(8):1191-1213

Raimbault P, Slawyk G, Coste B, Fry J (1990) Feasibility of using an automated colorimetric procedure for the determination of seawater nitrate in the 0 to $100 \mathrm{nM}$ range: Examples from field and culture. Mar. Biol 104:347-351

Relevante N, Gilmartin M (1982) Dynamics of phytoplankton in the Great Barrier Reef Lagoon. J Plankton Res 4(1): 47-76

Rodier M, Leborgne R (2010) Population and trophic dynamics of Trichodesmium thiebautii in the SE lagoon of New Caledonia. Comparison with T. erythraeum in the SW lagoon. Mar Poll Bull 61:349-359

Romans KM, Carpenter EJ, Bergman B (1994) Buoyancy regulation in the colonial diazotrophic cyanobacterium Trichodesmium tenue: Ultrastructure and storage of carbohydrate polyphosphate and nitrogen. J Phycol 30(6):935-942

Saito M, Hashihama F, Kitajima S, Takeda S, Furuya K (2010) Distribution of nano-sized Cyanobacteria in the western and central Pacific Ocean. Aqu Micr Ecology 59:273-282

Sarma TA (2012) Handbook of cyanobacteria. CRC Press, Science Publisher, pp 812

883 Shiozaki T, Kodama T, Furuya K (2014) Large-scale impact of the island mass effect through 884 nitrogen fixation in the western South Pacific Ocean. Geophys Res Lett 41: 2907-2913

Shiozaki T, Takeda S, Itoh S, Kodama T, Liu X, Hashihama F, Furuya K (2015) Why is Trichodesmium abundant in the Kuroshio? Biogeosciences 12:6931-6943

Sohm JA, Webb EA, Capone DG (2011) Emerging patterns of marine nitrogen fixation. Nat Rev Microbiol 9(7):499-508, doi:10.1038/nrmicro2594 
Tenório MMB, LeBorgne R, Rodier M, Neveux J (2005) The impact of terrigeneous inputs on the Bay of Ouinne (New Caledonia) phytoplankton communities: A spectrofluorometric and microscopic approach. Estuar Coast Shelf Sci 64:531-545

892 Utermöhl, von H. (1931) Neue Wege in der quantitativen Erfassung des Planktons. (Mit besondere Beriicksichtigung des Ultraplanktons). Verh Int Verein Theor Angew Limnol 5:

$894 \quad 567-595$

895 Van Den Broeck N, Moutin T, Rodier M, Le Bouteiller A (2004) Seasonal variations of 896 Phosphate availability in the SW Pacific Ocean near New Caledonia. Mar Ecol Prog Ser $897 \quad 268: 1-12$

898 Venrick EL (1974) The distribution and significance of Richelia intracellularis Schmidt in the 899 North Pacific Central Gyre. Limnol Oceanogr 19(3):437-445

900 Villareal TA, Carpenter EJ (2003) Buoyancy regulation and the potential for vertical migration 901 in the oceanic cyanobacterium Trichodesmium. Microb Ecol 45(1):1-10

902 Westberry T, Siegel DA (2006) Spatial and temporal distribution of Trichodesmium blooms in 903 the world's oceans. Glob Biogeochem Cy 20:GB4016, doi:10.1029/2005GB002673

904 Worden AZ, Nolan JK, Palenik B (2004) Assessing the dynamics and ecology of marine 905 picophytoplankton: The importance of the eukaryotic component, Limnol Oceanogr 49(1): $906 \quad 168-179$

907 Wyman M (1992) An in vivo method for the estimation of phycoerythrin concentrations in 908 marine cyanobacteria (Synechococcus spp.). Limnol Oceanogr 37: 1300-1306

909 Zehr JP, Bombar D (2015) Marine Nitrogen Fixation: Organisms Significance Enigmas and 910 Future Directions in Biological Nitrogen Fixation (ed de Bruijn FJ), John Wiley Sons Inc 911 Hoboken NJ USA, doi: 10,1002/9781119053095 
918 Table 1: Dates of the 9 Diapalis cruises

919

\begin{tabular}{ccc}
\hline Diapalis cruises & Dates & Austral Season \\
\hline D1 & 22-31 October 2001 & transition period \\
D2 & 10-22 December 2001 & Austral summer \\
D3 & 15-22 January 2002 & Austral summer \\
D4 & 2-9 April 2002 & Austral summer \\
D5 & 21-28 May 2002 & transition period \\
D6 & 6-13 August 2002 & Austral winter \\
D7 & 1-10 February 2003 & Austral summer \\
D8 & 10-14 June 2003 & Austral winter \\
D9 & 7-16 October 2003 & transition period \\
\hline
\end{tabular}

920

921

922

923

924

Table 2: Morphometric characteristics of filamentous cyanobacteria, in the $>10 \mu \mathrm{m}$ size fraction, encountered during the Diapalis cruises. NDO: not distinctly observed.

\begin{tabular}{|c|c|c|c|}
\hline Species & Cell diameter $(\mu \mathrm{m})$ & Cell length $(\mu \mathrm{m})$ & Cell shape \\
\hline T. erythraeum & 8 to 13.6 & 4 to 7 & $\begin{array}{l}\text { as wide as or up to } \\
\text { twice as wide as long }\end{array}$ \\
\hline T. thiebautii & 6 to 14 & 7 to 19 & $\begin{array}{l}\text { as long as or up to } \\
\text { twice as long as wide }\end{array}$ \\
\hline T. tenue & 4 to 5 & 12 to 20 & $\begin{array}{l}3 \text { to } 4 \times \text { longer than } \\
\text { wide }\end{array}$ \\
\hline T. contortum & 26 to 36 & 5 to 7 & $\begin{array}{l}5 \text { to } 6 \times \text { wider than } \\
\text { long }\end{array}$ \\
\hline T. hildebrandtii & $18-20$ & 5 to 6 & $\begin{array}{l}2.7 \text { to } 3 \times \text { wider than } \\
\text { long }\end{array}$ \\
\hline Unidentified filaments & 2.7 to 3 & $\mathrm{NDO}$ & $\mathrm{NDO}$ \\
\hline K. spiralis & 14 to 28 & 3 to 8 & $\begin{array}{l}2.2 \text { to } 4.8 \times \text { wider than } \\
\text { long }\end{array}$ \\
\hline K. pelagica & 17 to 28 & 2.5 to 3.5 & $\begin{array}{c}4 \text { to } 14 \mathrm{x} \text { wider than } \\
\text { long }\end{array}$ \\
\hline $\begin{array}{l}R \text {. intracellularis/C. } \\
\text { rhizosoleniae group }\end{array}$ & $\begin{array}{c}\text { cell 2-7 Ø } \\
\text { heterocyst 3-10 Ø }\end{array}$ & - & - \\
\hline $\begin{array}{l}\text { Colonies of } \\
\text { unidentified } \\
\text { cyanobacteria } \\
\text { (spherical cells) }\end{array}$ & $\begin{array}{c}\text { type } 1: 2.7-3 \varnothing \\
\text { type } 2: 6 \varnothing\end{array}$ & - & - \\
\hline
\end{tabular}

Table 3: A) Cell diameter $(\mu \mathrm{m})$ and B) cell length $(\mu \mathrm{m})$ of Trichodesmium and Katagnymene species. The colored areas represent size ranges published in the literature and shaded areas part 
929 of the size range observed during the Diapalis cruises in the New Caledonian Lagoon. A black 930 arrow indicates observation of a few T. erythraeum trichomes with a slightly wider diameter 931 than previously published.

A

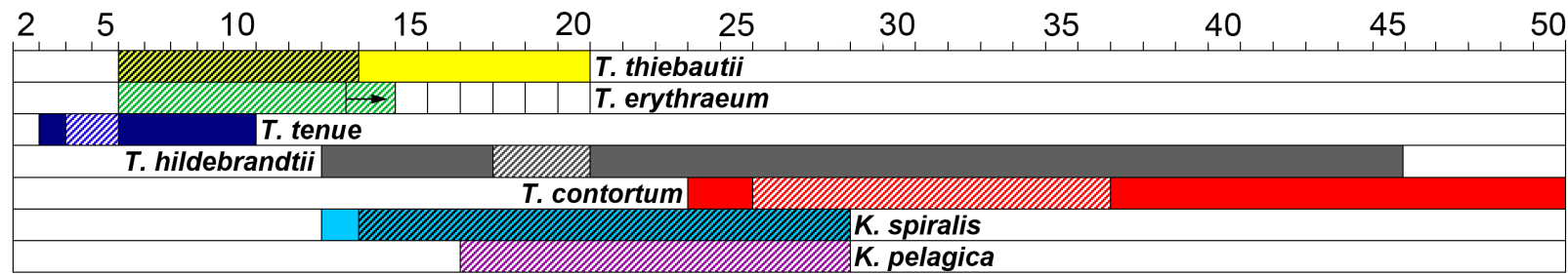

B

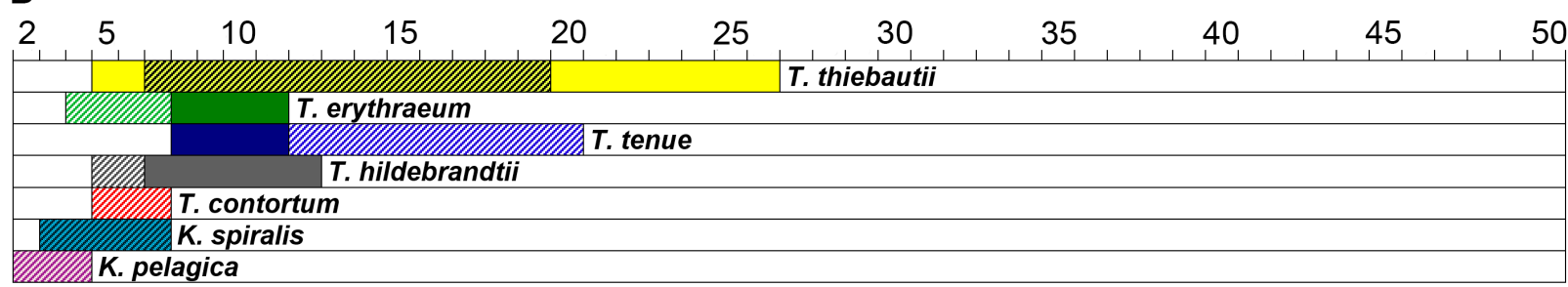

932

933

934

935

936

937

938

939

940

941

942

943

944

945

946 
Table 4. Statistical data for the different groups enumerated by inverted microscopy in the $>10 \mu \mathrm{m}$ fraction and by flow cytometry in the picoplanktonic fraction (trichome number for identified filamentous cyanobacteria and cell number for all other groups and the colonies of unidentified cyanobacteria with spherical cells), at ST1, the Santal Bay station, during the 9 Diapalis cruises (2001-2003). Concentrations taken at 4-6 depths down to $60 \mathrm{~m}\left(1^{-1}\right)$ and integrated values $\left(\mathrm{m}^{-2}\right)$ in the 0-60 $\mathrm{m}$ layer. Trichomes: sum of Trichodesmium and

954 Katagnymene trichomes.

\begin{tabular}{|c|c|c|c|c|c|}
\hline ST1 Diapalis 01-09 & $\min$ & $\max$ & average & stdev & $\mathbf{n}$ \\
\hline Trichomes $1^{-1}$ & 1 & 2929 & 651 & 648 & 50 \\
\hline $10^{6}$ Trichomes $\mathrm{m}^{-2}$ & 0.06 & 89 & 38 & 30 & 12 \\
\hline $10^{6} \mu \mathrm{m}^{3}$ Trichomes $1^{-1}$ & 0.59 & 49.22 & 11.46 & 12.70 & 25 \\
\hline $10^{9} \mu \mathrm{m}^{3}$ Trichome $\mathrm{m}^{-2}$ & 0.16 & 1.15 & 0.52 & 0.37 & 7 \\
\hline R. intracellularis/C. rhizosoleniae group $1^{-1}$ & 0 & 64 & 8 & 16 & 25 \\
\hline $\begin{array}{l}10^{3} \mu \mathrm{m}^{3} R \text {. intracellularis/ } \\
\text { C. rhizosoleniae group } 1^{-1}\end{array}$ & 0.00 & 12.76 & 1.13 & 2.74 & 24 \\
\hline $\begin{array}{l}\text { Unidentified cyanobacteria with } \\
\text { spherical cells }\left(\text { cell } 1^{-1}\right)\end{array}$ & 0 & 20 & 1 & 5 & 25 \\
\hline Dinoflagellates $1^{-1}$ & 22 & 1927 & 322 & 405 & 31 \\
\hline Diatoms $1^{-1}$ & 14 & 4516 & 640 & 1096 & 31 \\
\hline T. tenue $1^{-1}$ & 20 & 947 & 285 & 255 & 28 \\
\hline T. erythraeum $1^{-1}$ & 3 & 621 & 145 & 159 & 28 \\
\hline T. thiebautii $1^{-1}$ & 18 & 1351 & 335 & 353 & 28 \\
\hline K. spiralis $\mathrm{1}^{-1}$ & 0 & 199 & 29 & 49 & 28 \\
\hline K. pelagica $1^{-1}$ & 0 & 61 & 6 & 14 & 28 \\
\hline $10^{6} \mu \mathrm{m}^{3} T$. tenue $\mathrm{I}^{-1}$ & 0.09 & 7.82 & 2.20 & 2.25 & 27 \\
\hline $10^{6} \mu \mathrm{m}^{3} T$. erythraeum $1^{-1}$ & 0.02 & 15.41 & 2.46 & 3.66 & 27 \\
\hline $10^{6} \mu \mathrm{m}^{3} T$. thiebautii $1^{-1}$ & 0.18 & 13.90 & 3.67 & 3.64 & 27 \\
\hline $10^{6} \mu \mathrm{m}^{3} K$. spiralis $\mathrm{1}^{-1}$ & 0.00 & 6.90 & 1.33 & 1.98 & 27 \\
\hline $10^{6} \mu \mathrm{m}^{3} \mathrm{~K}$. pelagica $\mathrm{l}^{-1}$ & 0.00 & 31.40 & 1.54 & 6.04 & 27 \\
\hline $10^{4}$ Prochlorococcus $\mathrm{ml}^{-1}$ & 3.73 & 46.21 & 13.37 & 8.13 & 76 \\
\hline $10^{4}$ Synechococcus $\mathrm{ml}^{-1}$ & 0.22 & 3.58 & 1.50 & 0.86 & 76 \\
\hline $10^{4}$ Picoeukaryotes $\mathrm{ml}^{-1}$ & 0.06 & 0.47 & 0.18 & 0.08 & 76 \\
\hline $10^{12}$ Prochlorococcus $\mathrm{m}^{-2}$ & 3.41 & 14.80 & 8.76 & 3.96 & 11 \\
\hline $10^{12}$ Synechococcus $\mathrm{m}^{-2}$ & 0.19 & 1.75 & 0.94 & 0.49 & 11 \\
\hline $10^{12}$ Picoeukaryotes $\mathrm{m}^{-2}$ & 0.06 & 0.17 & 0.11 & 0.04 & 11 \\
\hline
\end{tabular}

955

956

957

958

959

960

961

962

963

964

965 
Table 5. Statistical data for the different groups enumerated by inverted microscopy in the $>10 \mu \mathrm{m}$ fraction and by flow cytometry in the picoplanktonic fraction (trichome number for identified filamentous cyanobacteria and cell number for all other groups and the colonies of unidentified cyanobacteria with spherical cells), at the ST2, Loyalty Channel station, during the 9 Diapalis cruises (2001-2003). Concentrations taken at 4-6 depths down to $60 \mathrm{~m}$ $\left(1^{-1}\right)$ and integrated values $\left(\mathrm{m}^{-2}\right)$ in the $0-60 \mathrm{~m}$ layer. Trichomes: sum of Trichodesmium and

973 Katagnymene trichomes

\begin{tabular}{|c|c|c|c|c|c|}
\hline ST2 Diapalis 01-09 & $\min$ & $\max$ & average & stdev & $\mathbf{n}$ \\
\hline Trichomes $1^{-1}$ & 4 & 4578 & 676 & 1089 & 45 \\
\hline $10^{6}$ Trichomes $\mathrm{m}^{-2}$ & 0.46 & 235 & 44 & 66 & 11 \\
\hline $10^{6} \mu \mathrm{m}^{3}$ Trichome $1^{-1}$ & 0.03 & 62.22 & 9.53 & 15.29 & 36 \\
\hline $10^{9} \mu \mathrm{m}^{3}$ Trichome $\mathrm{m}^{-2}$ & 0.16 & 3.05 & 0.63 & 0.92 & 9 \\
\hline R. intracellularis/C. rhizosoleniae group $\mathrm{l}^{-1}$ & 0 & 735 & 36 & 121 & 41 \\
\hline $\begin{array}{l}10^{3} \mu \mathrm{m}^{3} R \text {. intracellularis/ } \\
\text { C. rhizosoleniae group } \mathrm{l}^{-1}\end{array}$ & 0.00 & 117.33 & 7.22 & 21.64 & 30 \\
\hline $\begin{array}{l}\text { Unidentified cyanobacteria with } \\
\text { spherical cells }\left(\text { cell } l^{-1}\right)\end{array}$ & 0 & 4934 & 224 & 833 & 40 \\
\hline Dinoflagellates $1^{-1}$ & 8 & 1205 & 289 & 306 & 40 \\
\hline Diatoms $1^{-1}$ & 5 & 9969 & 834 & 2190 & 40 \\
\hline T. tenue $1^{-1}$ & 13 & 1053 & 209 & 250 & 36 \\
\hline T. erythraeum $1^{-1}$ & 2 & 417 & 50 & 78 & 36 \\
\hline T. thiebautii $1^{-1}$ & 3 & 635 & 136 & 150 & 36 \\
\hline K. spiralis $1^{-1}$ & 0 & 31 & 3 & 6 & 36 \\
\hline K. pelagica $1^{-1}$ & 0 & 11 & 2 & 3 & 36 \\
\hline $10^{6} \mu \mathrm{m}^{3} T$. tenиe $\mathrm{I}^{-1}$ & 0.04 & 17.28 & 2.88 & 3.49 & 32 \\
\hline $10^{6} \mu \mathrm{m}^{3}$ T. erythraeum $\mathrm{1}^{-1}$ & 0.01 & 17.97 & 1.99 & 3.88 & 32 \\
\hline $10^{6} \mu \mathrm{m}^{3} T$. thiebautii $1^{-1}$ & 0.13 & 21.03 & 2.92 & 4.66 & 32 \\
\hline $10^{6} \mu \mathrm{m}^{3} \mathrm{~K}$. spiralis $1^{-1}$ & 0.00 & 15.89 & 0.82 & 2.90 & 32 \\
\hline $10^{6} \mu \mathrm{m}^{3} \mathrm{~K}$. pelagica $\mathrm{1}^{-1}$ & 0.00 & 2.07 & 0.18 & 0.46 & 32 \\
\hline $10^{4}$ Prochlorococcus $\mathrm{ml}^{-1}$ & 2.59 & 29.02 & 13.05 & 5.95 & 111 \\
\hline $10^{4}$ Synechococcus $\mathrm{ml}^{-1}$ & 0.05 & 4.58 & 0.99 & 1.24 & 111 \\
\hline $10^{4}$ Picoeukaryotes $\mathrm{ml}^{-1}$ & 0.03 & 0.67 & 0.11 & 0.08 & 111 \\
\hline $10^{12}$ Prochlorococcus $\mathrm{m}^{-2}$ & 3.53 & 14.87 & 8.76 & 3.59 & 17 \\
\hline $10^{12}$ Synechococcus $\mathrm{m}^{-2}$ & 0.08 & 2.55 & 0.62 & 0.79 & 17 \\
\hline $10^{12}$ Picoeukaryotes $\mathrm{m}^{-2}$ & 0.02 & 0.15 & 0.07 & 0.04 & 17 \\
\hline
\end{tabular}

974

975

976

977

978

979

980

981

982

983

984 
Table 6. Statistical data for the different groups enumerated by inverted microscopy in the $>10 \mu \mathrm{m}$ fraction and by flow cytometry in the picoplanktonic fraction (trichome number for identified filamentous cyanobacteria and cell number for all other groups and the colonies of unidentified cyanobacteria with spherical cells), at ST3, the Ouinne station, Eastern Lagoon, during the 9 Diapalis cruises (2001-2003). Concentrations taken at 4-6 depths down 992 to $30 \mathrm{~m}\left(1^{-1}\right)$ and integrated values $\left(\mathrm{m}^{-2}\right)$ in the 0-30 m layer. Trichomes: sum of Trichodesmium and Katagnymene trichomes.

\begin{tabular}{|c|c|c|c|c|c|}
\hline ST3 Diapalis 01-09 & $\min$ & $\max$ & average & stdev & $\mathbf{n}$ \\
\hline Trichomes $1^{-1}$ & 10 & 854 & 172 & 219 & 32 \\
\hline $10^{3}$ Trichomes $\mathrm{m}^{-2}$ & 0.38 & 15.00 & 4.74 & 5.30 & 9 \\
\hline $10^{6} \mu \mathrm{m}^{3}$ Trichomes $1^{-1}$ & 0.07 & 10.19 & 2.67 & 2.81 & 20 \\
\hline $10^{9} \mu \mathrm{m}^{3}$ Trichome $\mathrm{m}^{-2}$ & 0.01 & 0.18 & 0.09 & 0.07 & 5 \\
\hline R. intracellularis/C. rhizosoleniae group $\mathrm{l}^{-1}$ & 0 & 117 & 15 & 25 & 25 \\
\hline $\begin{array}{l}10^{3} \mu \mathrm{m}^{3} R \text {. intracellularis/ } \\
\text { C. rhizosoleniae group } 1^{-1}\end{array}$ & 0 & 64.90 & 7.25 & 14.36 & 23 \\
\hline $\begin{array}{l}\text { Unidentified cyanobacteria with } \\
\text { spherical cells (cell } l^{-1} \text { ) }\end{array}$ & 0 & 429 & 22 & 88 & 24 \\
\hline Dinoflagellates $1^{-1}$ & 82 & 1000 & 344 & 251 & 22 \\
\hline Diatoms $1^{-1}$ & 26 & 16893 & 2458 & 4345 & 22 \\
\hline T. tenue $\mathrm{l}^{-1}$ & 5 & 868 & 136 & 228 & 29 \\
\hline T. erythraeum $1^{-1}$ & 0 & 132 & 16 & 28 & 29 \\
\hline T. thiebautii $1^{-1}$ & 2 & 147 & 43 & 40 & 29 \\
\hline K. spiralis $1^{-1}$ & 0 & 9 & 0 & 2 & 29 \\
\hline K. pelagica $1^{-1}$ & 0 & 8 & 0 & 2 & 29 \\
\hline $10^{6} \mu \mathrm{m}^{3}$ T. tenиe $\mathrm{I}^{-1}$ & 0.08 & 6.09 & 1.61 & 2.10 & 18 \\
\hline $10^{6} \mu \mathrm{m}^{3}$ T. erythraeum $1^{-1}$ & 0.00 & 4.79 & 0.66 & 1.14 & 18 \\
\hline $10^{6} \mu \mathrm{m}^{3} T$. thiebautii $1^{-1}$ & 0.02 & 2.41 & 0.89 & 0.68 & 18 \\
\hline $10^{6} \mu \mathrm{m}^{3} K$. spiralis $1^{-1}$ & 0.00 & 0.50 & 0.03 & 0.12 & 18 \\
\hline $10^{6} \mu \mathrm{m}^{3} \mathrm{~K}$. pelagica $1^{-1}$ & 0.00 & 1.42 & 0.10 & 0.35 & 18 \\
\hline $10^{4}$ Prochlorococcus $\mathrm{ml}^{-1}$ & 1.01 & 24.17 & 7.28 & 4.40 & 66 \\
\hline $10^{4}$ Synechococcus $\mathrm{ml}^{-1}$ & 1.14 & 13.82 & 6.60 & 2.91 & 66 \\
\hline $10^{4}$ Picoeukaryotes $\mathrm{ml}^{-1}$ & 0.13 & 1.74 & 0.34 & 0.26 & 66 \\
\hline $10^{12}$ Prochlorococcus $\mathrm{m}^{-2}$ & 0.48 & 4.75 & 2.13 & 1.05 & 11 \\
\hline $10^{12}$ Synechococcus $\mathrm{m}^{-2}$ & 0.82 & 3.27 & 1.92 & 0.79 & 11 \\
\hline $10^{12}$ Picoeukaryotes $\mathrm{m}^{-2}$ & 0.06 & 0.17 & 0.10 & 0.04 & 11 \\
\hline
\end{tabular}

994

995 Table 7: Cell number per trichome of each Trichodesmium and Katagnymene species during the

996

997 Diapalis cruises.

\begin{tabular}{cccccccc}
\hline & T. tenue & T. thiebautii & T. erythraeum & T. hildebrandtii & T. contortum & K. spiralis & K. pelagica \\
\hline min & 3 & 3 & 4 & 16 & 19 & 2 & 10 \\
$\max$ & 206 & 209 & 235 & 132 & 62 & 140 & 334 \\
Mean & 54 & 55 & 64 & 62 & 40 & 42 & 57 \\
STD & 36 & 38 & 45 & 40 & 22 & 34 & 77 \\
N & 584 & 469 & 322 & 9 & 3 & 49 & 18 \\
\hline
\end{tabular}


Table 8: Morphometric characteristics of Trichodesmium and Katagnymene species at the Trichodesmium peak abundance in February 03 (Diapalis 7). Their chlorophyll $a$ (Chla), phycoerythrin (PE), carbon (C) content per trichome and volume of trichome. Comparison with cellular characteristics, pigments and carbon content obtained with T. erythraeum in New Caledonian waters (West Coast). TK: sum of Trichodesmium and Katagnymene trichomes.

\begin{tabular}{|c|c|c|c|}
\hline & Mean & STD & Number \\
\hline \multicolumn{4}{|l|}{ D7 Cruise } \\
\hline pg Chla trichome ${ }^{-1}$ & 43.23 & 18.86 & 30 \\
\hline$\mu \mathrm{g} \mathrm{Chl} a \mathrm{~mm}^{-3}$ trichome & 3.47 & 1.71 & 23 \\
\hline pg PE trichome ${ }^{-1}$ & 196.86 & 58.34 & 30 \\
\hline$\mu \mathrm{g} \mathrm{PE} \mathrm{mm}^{-3}$ trichome & 16.71 & 7.94 & 24 \\
\hline TK trichome diameter $(\mu \mathrm{m})$ & 6.64 & 3.32 & 1884 \\
\hline TK trichome length $(\mu \mathrm{m})$ & 360 & 302 & 1884 \\
\hline TK trichome volume $\left(\mu \mathrm{m}^{3}\right)$ & 12808 & 28847 & 1884 \\
\hline T. contortum trichome diameter $(\mu \mathrm{m})$ & 33.00 & - & 2 \\
\hline T. contortum trichome length $(\mu \mathrm{m})$ & 128 & - & 2 \\
\hline T. erythraeum trichome diameter $(\mu \mathrm{m})$ & 8.01 & 1.11 & 402 \\
\hline T. erythraeum trichome length $(\mu \mathrm{m})$ & 320 & 245 & 402 \\
\hline T. hidelbrandtii trichome diameter $(\mu \mathrm{m})$ & 16.00 & 2.49 & 9 \\
\hline T. hidelbrandtii trichome length $(\mu \mathrm{m})$ & 269 & 308 & 9 \\
\hline T. tenue trichome diameter $(\mu \mathrm{m})$ & 4.49 & 0.57 & 530 \\
\hline T. tenue trichome length $(\mu \mathrm{m})$ & 472 & 357 & 530 \\
\hline T. thiebautii trichome diameter $(\mu \mathrm{m})$ & 6.06 & 0.28 & 735 \\
\hline T. thiebautii trichome length $(\mu \mathrm{m})$ & 327 & 273 & 735 \\
\hline K. pelagica trichome diameter $(\mu \mathrm{m})$ & 24.00 & 5.10 & 5 \\
\hline$K$. pelagica trichome length $(\mu \mathrm{m})$ & 403 & 558 & 5 \\
\hline$K$. spiralis trichome diameter $(\mu \mathrm{m})$ & 20.00 & 3.95 & 65 \\
\hline K. spiralis trichome length $(\mu \mathrm{m})$ & 170 & 189 & 65 \\
\hline \multicolumn{4}{|l|}{ T. erythraeum } \\
\hline pg Chl $a$ cell $^{-1}$ & 1.58 & 0.26 & 5 \\
\hline pg Chla trichome ${ }^{-1}$ & 99.00 & 14.62 & 5 \\
\hline ng Chl $a \mathrm{~mm}^{-3}$ trichome & 3.31 & 3.86 & 5 \\
\hline pg PE cell ${ }^{-1}$ & 4.01 & 0.76 & 5 \\
\hline pg PE trichome ${ }^{-1}$ & 251.57 & 41.26 & 5 \\
\hline$\mu \mathrm{g} \mathrm{PE} \mathrm{mm}^{-3}$ trichome & 8.37 & 1.21 & 5 \\
\hline pg carbon cell ${ }^{-1}$ & 289.89 & - & 2 \\
\hline ng carbon trichome ${ }^{-1}$ & 17.22 & - & 2 \\
\hline$\mu \mathrm{g}$ carbon $\mathrm{mm}^{-3}$ trichome & 588.06 & - & 2 \\
\hline $\mathrm{PE} / \mathrm{Chl} a$ & 3.81 & 1.79 & 13 \\
\hline Carbon/Chla & 173.21 & 55.96 & 9 \\
\hline Carbon/PE & 71.15 & 33.54 & 6 \\
\hline Cell diameter $(\mu \mathrm{m})$ & 9.6 & 0.5 & 1849 \\
\hline Cell length $(\mu \mathrm{m})$ & 6.3 & 0.7 & 1849 \\
\hline Cell volume $\left(\mu \mathrm{m}^{3}\right)$ & 456 & 76 & 1849 \\
\hline Trichome length $(\mu \mathrm{m})$ & 402 & 157 & 1849 \\
\hline
\end{tabular}


Table 9. Spearman's correlation coefficient for the relationships between integrated abundance (cell or trichomes $\mathrm{m}^{-2}$ over $60 \mathrm{~m}$ for ST1 and ST2 and $30 \mathrm{~m}$ for ST3) of autotrophic groups, the percentage of the different species of filamentous cyanobacteria and environmental parameters $(\mathrm{n}=28)$. Data from the Diapalis cruises $(2001-2003) .{ }^{*} \mathrm{p}<0.01,{ }^{*} \mathrm{p}<0.05$, ns: not significant; TK: sum of Trichodesmium and Katagnymene trichomes; Din: Dinoflagellates; Diat: Diatoms; Rich: Richelia; Proc: Prochlorococcus; Syn: Synechococcus; Peuk: Picoeukaryotes; T.t: T. tenue; T. e: T. erythraeum; T. th: T. thiebautii; K. s: K. spiralis; K. p.: K. pelagica; MLD: mixed layer depth; $\mathrm{T}\left({ }^{\circ} \mathrm{C}\right)$ : Temperature; Sal: Salinity.

\begin{tabular}{|c|c|c|c|c|c|c|c|c|c|c|c|c|c|c|c|c|c|c|}
\hline Variables & Din & Diat & TK & Rich & Proc & Syn & Peuk & $\%$ T.t & \%T.e & \%T.th & $\% K . s$ & $\% K \cdot p$ & MLD & $\mathrm{T}\left({ }^{\circ} \mathrm{C}\right)$ & Sal & $\mathrm{NO}_{\mathrm{x}}$ & $\mathrm{NH}_{4}$ & $\mathrm{PO}_{4}$ \\
\hline Din & 1 & $0.46^{* *}$ & $0.63^{* *}$ & ns & $\mathrm{ns}$ & ns & $\mathrm{ns}$ & ns & $0.50 * *$ & $\mathrm{~ns}$ & $\mathrm{~ns}$ & $-0.57 * *$ & ns & ns & ns & ns & $\mathrm{ns}$ & $\mathrm{ns}$ \\
\hline Diat & & 1 & $\mathrm{~ns}$ & ns & ns & ns & ns & ns & ns & ns & ns & ns & ns & ns & ns & ns & ns & ns \\
\hline TK & & & 1 & ns & $0.65^{*}$ & ns & ns & ns & $\mathrm{ns}$ & $\mathrm{ns}$ & ns & ns & ns & $0.62^{*}$ & ns & ns & $0.51 * *$ & $-0.48^{* *}$ \\
\hline Rich & & & & 1 & ns & ns & ns & ns & ns & $0.61 *$ & $0.69^{*}$ & ns & $0.60^{* *}$ & ns & ns & ns & $0.85^{*}$ & ns \\
\hline Proc & & & & & 1 & $-0.42 * *$ & $\mathrm{~ns}$ & ns & ns & $-0.50 * *$ & $\mathrm{~ns}$ & ns & ns & ns & ns & ns & ns & ns \\
\hline Syn & & & & & & 1 & $0.52 * *$ & ns & ns & ns & ns & ns & ns & ns & ns & ns & ns & ns \\
\hline Peuk & & & & & & & 1 & ns & ns & ns & ns & ns & ns & ns & ns & ns & ns & ns \\
\hline$\% T . t$ & & & & & & & & 1 & ns & $-0.65^{*}$ & $-0.59 * *$ & ns & ns & $0.49^{* *}$ & ns & ns & $-0.57 * *$ & ns \\
\hline$\%$ T.e & & & & & & & & & 1 & ns & ns & ns & ns & ns & ns & ns & ns & ns \\
\hline$\%$ T.th & & & & & & & & & & 1 & ns & $\mathrm{ns}$ & ns & $\mathrm{ns}$ & ns & $\mathrm{ns}$ & $\mathrm{ns}$ & $\mathrm{ns}$ \\
\hline$\% K . s$ & & & & & & & & & & & 1 & ns & ns & ns & ns & $0.64 * *$ & $0.55^{* *}$ & $0.59 * *$ \\
\hline$\% K . p$ & & & & & & & & & & & & 1 & ns & ns & ns & ns & $\mathrm{ns}$ & $0.63^{* *}$ \\
\hline MLD & & & & & & & & & & & & & 1 & ns & ns & $-0.46^{* *}$ & ns & ns \\
\hline $\mathrm{T}\left({ }^{\circ} \mathrm{C}\right)$ & & & & & & & & & & & & & & 1 & $-0.63^{*}$ & ns & ns & $-0.55^{*}$ \\
\hline Sal & & & & & & & & & & & & & & & 1 & ns & ns & $0.52 * *$ \\
\hline $\mathrm{NO}_{\mathrm{x}}$ & & & & & & & & & & & & & & & & 1 & ns & $0.48^{* *}$ \\
\hline $\mathrm{NH}_{4}$ & & & & & & & & & & & & & & & & & 1 & ns \\
\hline $\mathrm{PO}_{4}$ & & & & & & & & & & & & & & & & & & 1 \\
\hline
\end{tabular}



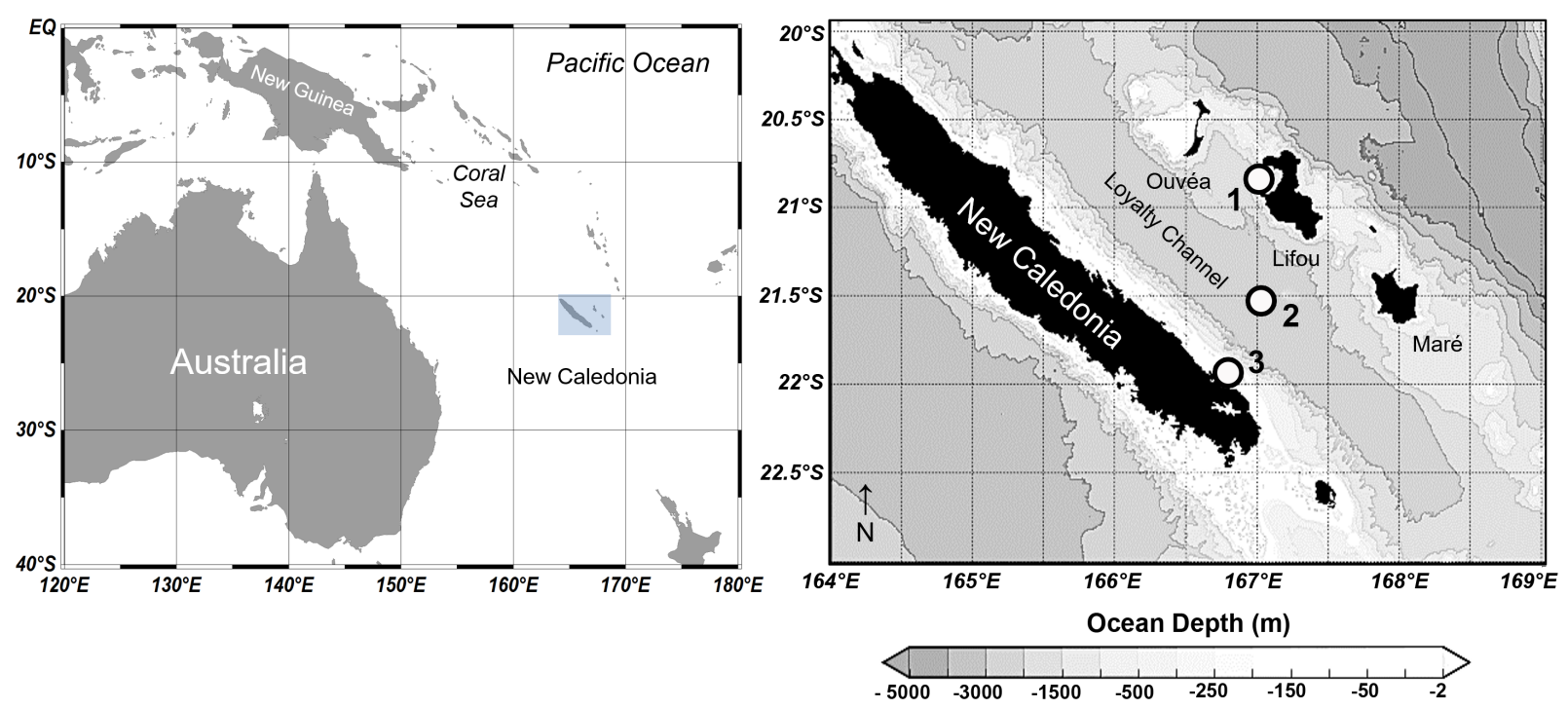

Figure 1. Location of the 3 main stations sampled during the nine Diapalis cruises in the New

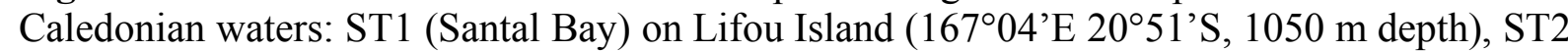
(Loyalty Channel, $167^{\circ} \mathrm{E} 21^{\circ} 30^{\prime} \mathrm{S}, 2100 \mathrm{~m}$ depth) and ST3 (Ouinne station) in the East Coast lagoon (166 $45^{\prime} \mathrm{E} 21^{\circ} 57^{\prime} \mathrm{S}, 35 \mathrm{~m}$ depth). Figure Courtesy J. Lefèvre. 
A

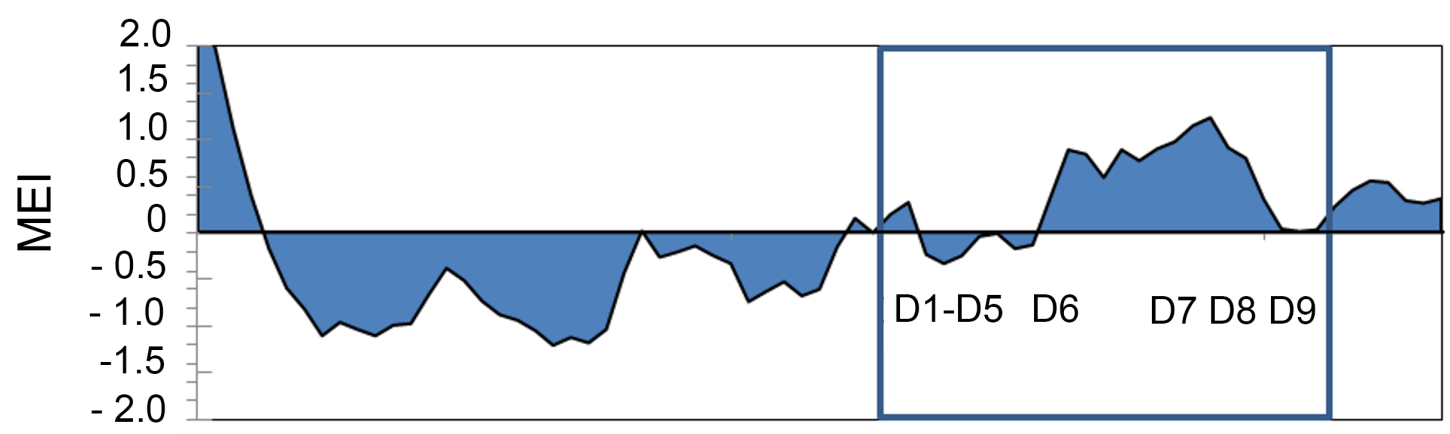

B

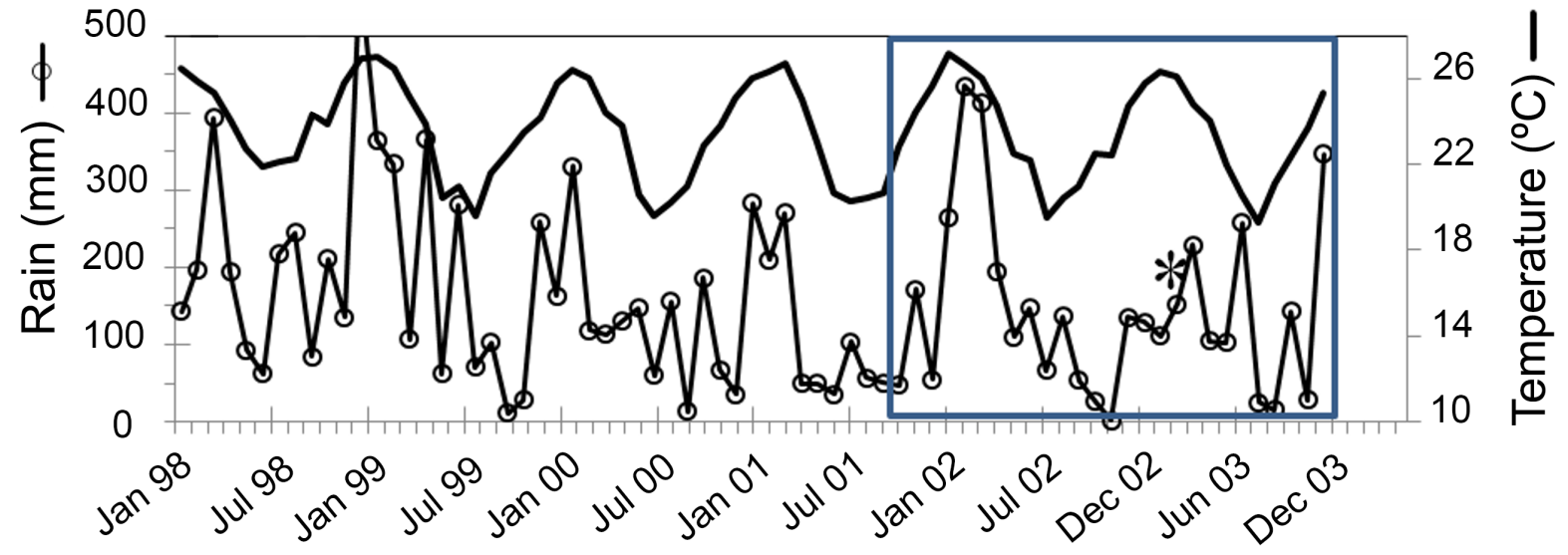

Figure 2. (A) Multivariate El Nino Index, (B) air temperature and $\left(\mathrm{T}{ }^{\circ} \mathrm{C}\right)$ and monthly cumulative precipitation (mm) for 1998-2003 on New Caledonia's east coast (Thio station). The framed area represents the Diapalis sampling period. Tropical Storm Beni (29 Jan - 5 Feb 2003) 

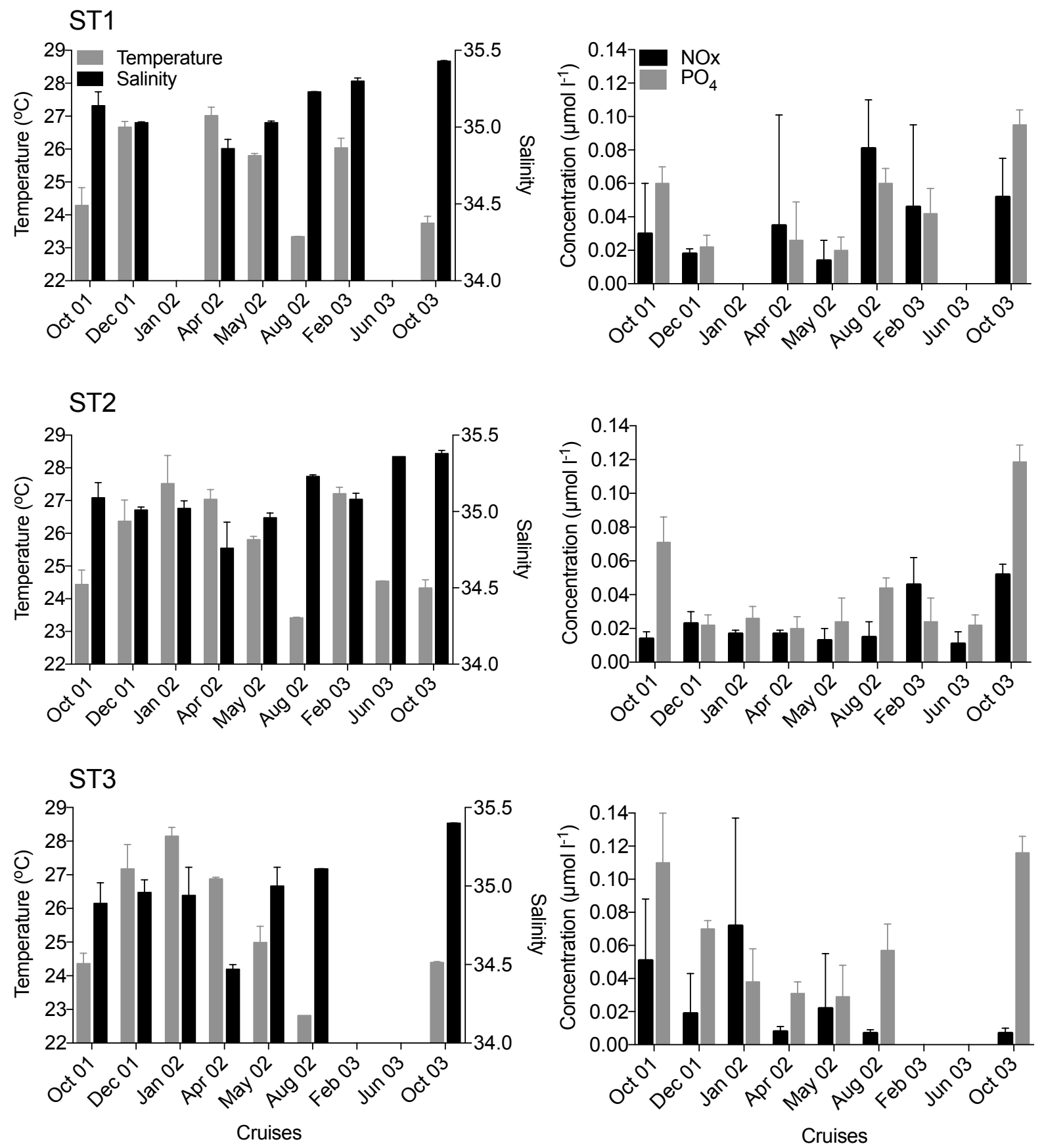

Figure 3. Mean temperature, salinity (left panel) and nutrients $\left(\mathrm{NO}_{\mathrm{x}}, \mathrm{PO}_{4}^{-}\right)$(right panel) during the Diapalis cruises. Values are averaged from 0-60 $\mathrm{m}$ at ST1 and ST2 and 0-30 $\mathrm{m}$ at ST3. ST3 was not sampled in Feb 03 and Jun 03. 

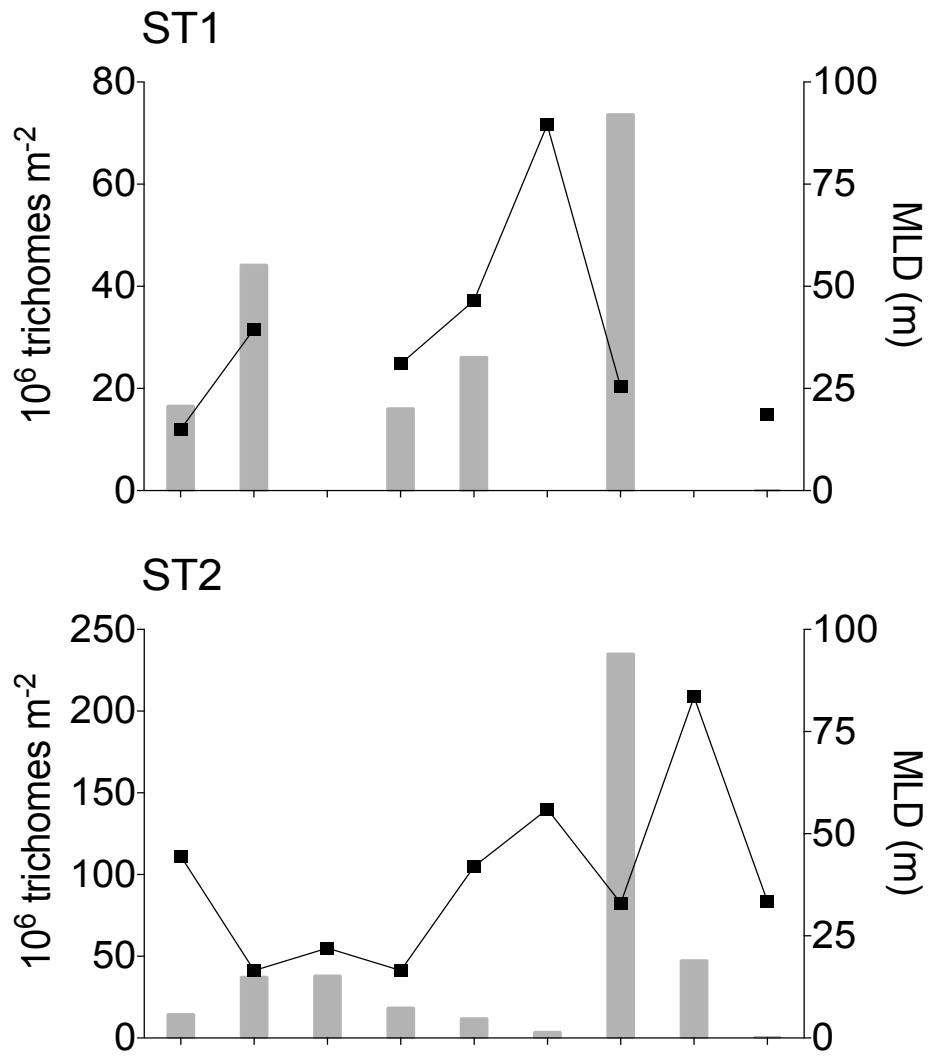

ST3

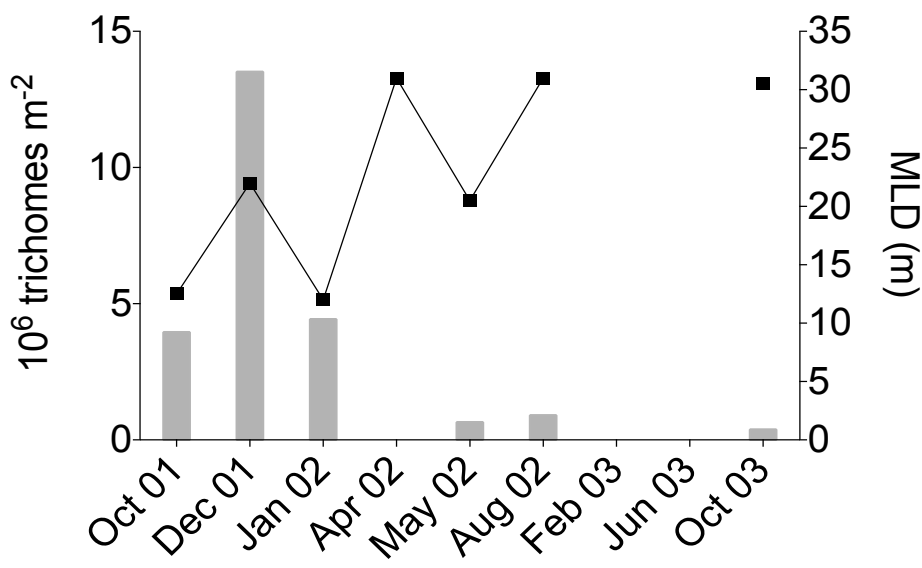

Cruises

1047 Figure 4. Integrated concentrations of the total filamentous cyanobacteria (trichomes $\mathrm{m}^{-2}$ ) in 1048 the $>10 \mu \mathrm{m}$ fraction (R. intracellularis and $C$. rhizosoleniae not included) (bars) and the 1049 mixed layer depth (MLD) (lines) during the Diapalis cruises. Integration depths: 0-60 $\mathrm{m}$ at $1050 \quad$ ST1 and ST2 and $30 \mathrm{~m}$ at ST3. 

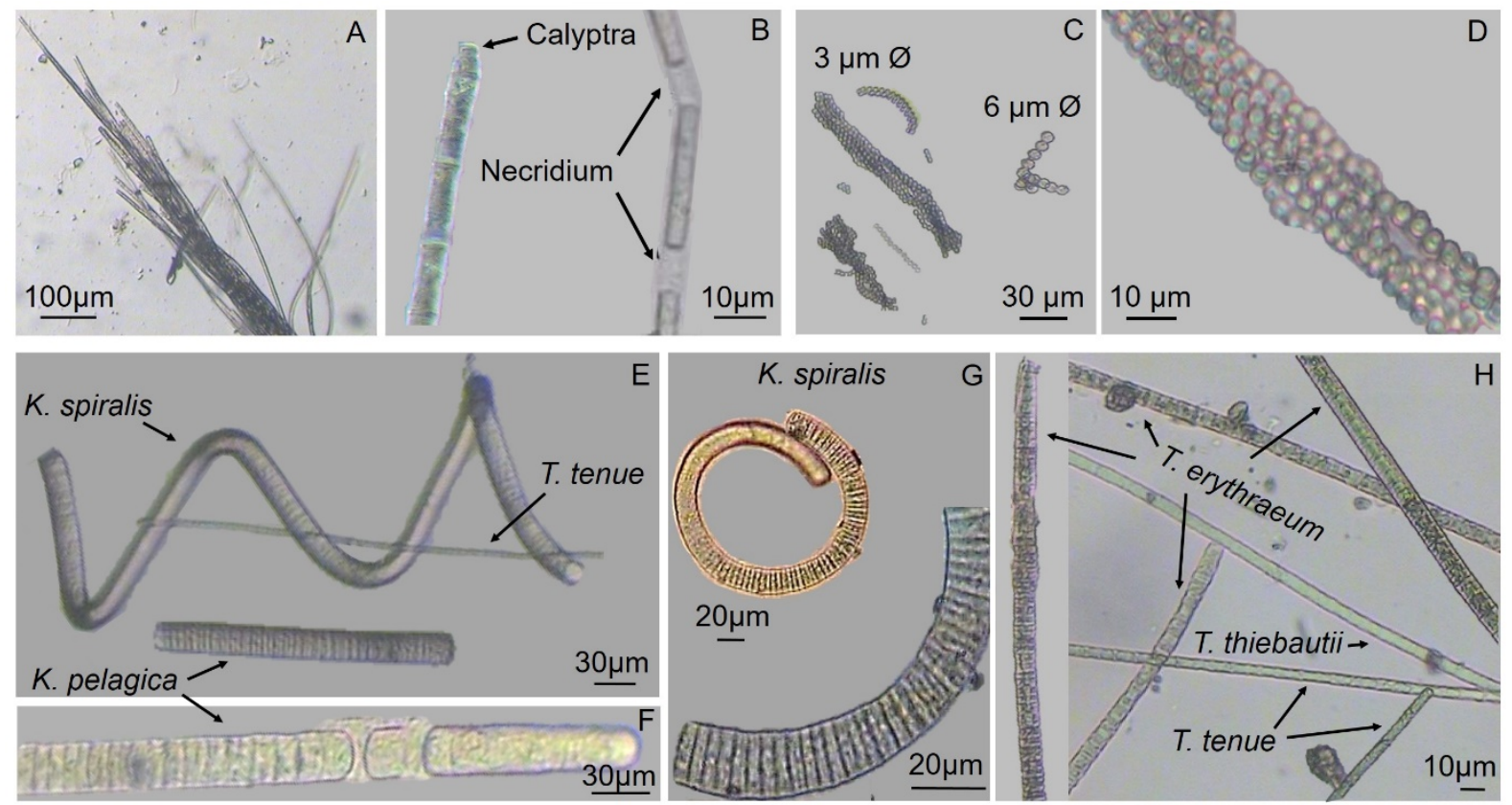

1053

1054

1055

1056

1057

1058

1059

1060

1061

1062

1063

1064

1065

1066

1067

1068

1069

1070

Figure 5. Photomicrographs of filamentous cyanobacteria obtained from the Diapalis cruises.

A) Trichodesmium tenue, B) Details of T. tenue trichomes: note that cell length is about 3 times longer than wide; the calyptra (formation at the tip of the trichome) and the necridium (structure formed from a dead cell which constitutes a fracture point of the filament). C) Colonies of unidentified cyanobacteria composed of round-shaped cells. Type 1, $3 \mu \mathrm{m} \varnothing$ and Type 2, $6 \mu \mathrm{m} \varnothing$ and D) details of Type-1. E-G) Katagnymene spiralis and Katagnymene pelagica. Note the size difference between Katagnymene spp. and T. tenue. H) Mix of major species (T. erythraeum, $T$, tenue, T. thiebautii).
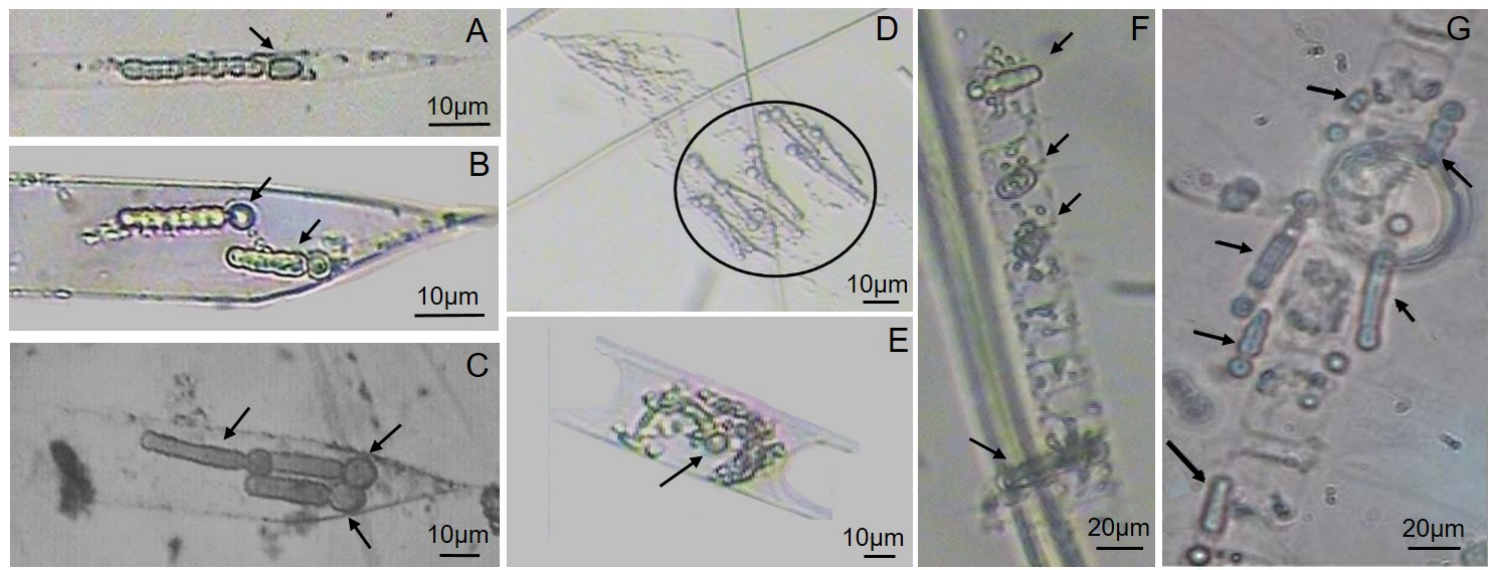

Figure 6. A-D) Richelia intracellularis symbiotic with Rhizosolenia spp. and E) Hemiaulus sp.; F-G) Calothrix rhizosoleniae epiphyte on Chaetoceros sp. Size and number of Richelia vary based on the size of the host. Photomicrographs obtained from the Diapalis cruises. 

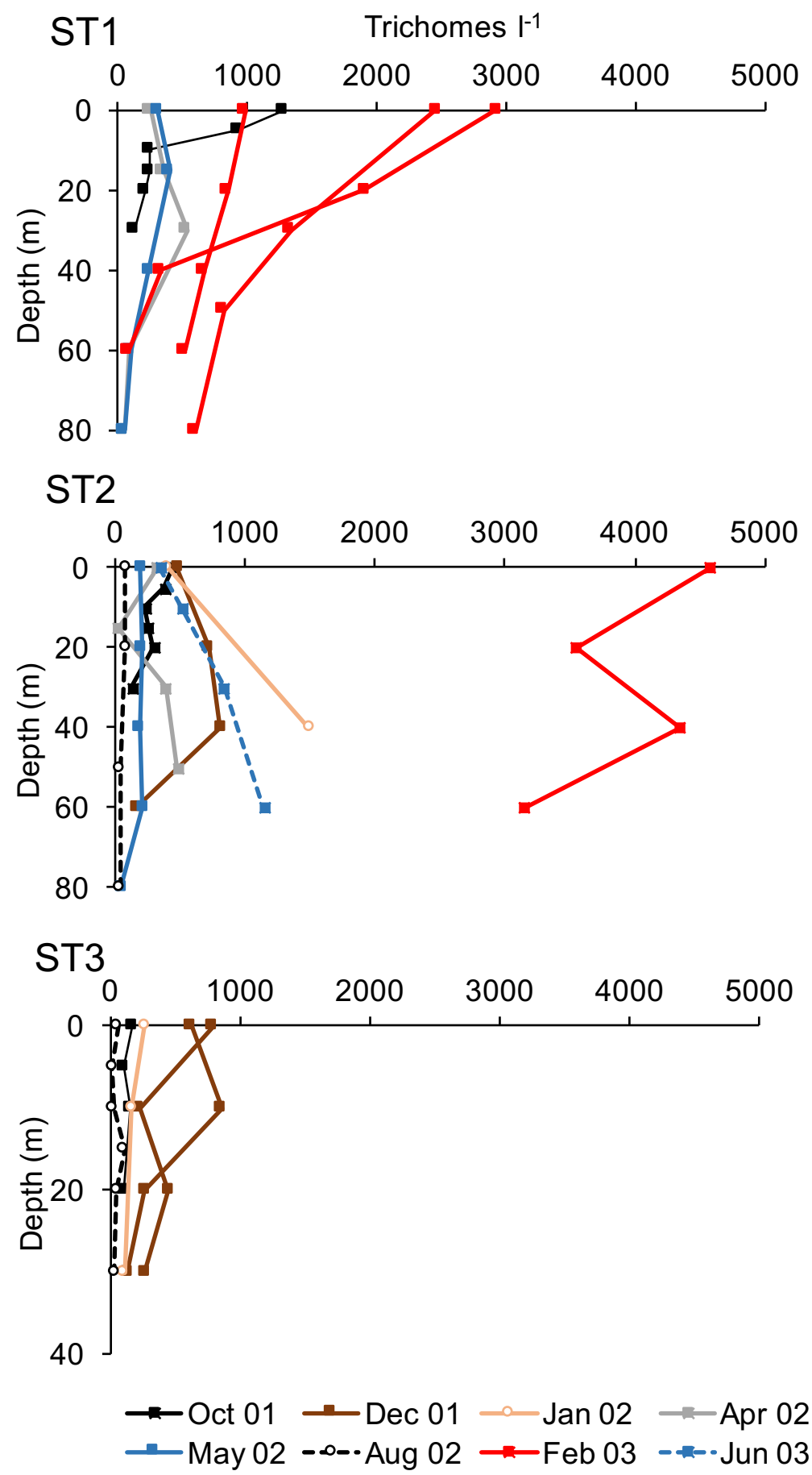

Cruises

1074 Figure 7. Vertical profiles for filamentous cyanobacteria abundance (Trichomes $1^{-1}$ ) (except $R$. intracellularis and $C$. rhizosoleniae) during the Diapalis cruise stations. ST2 (open ocean, Loyalty Channel) is well representative of the seasonal variations (some cruises are missing at ST1 and ST3). Note that at ST1 in February 2003, 3 profiles were performed with intervals 

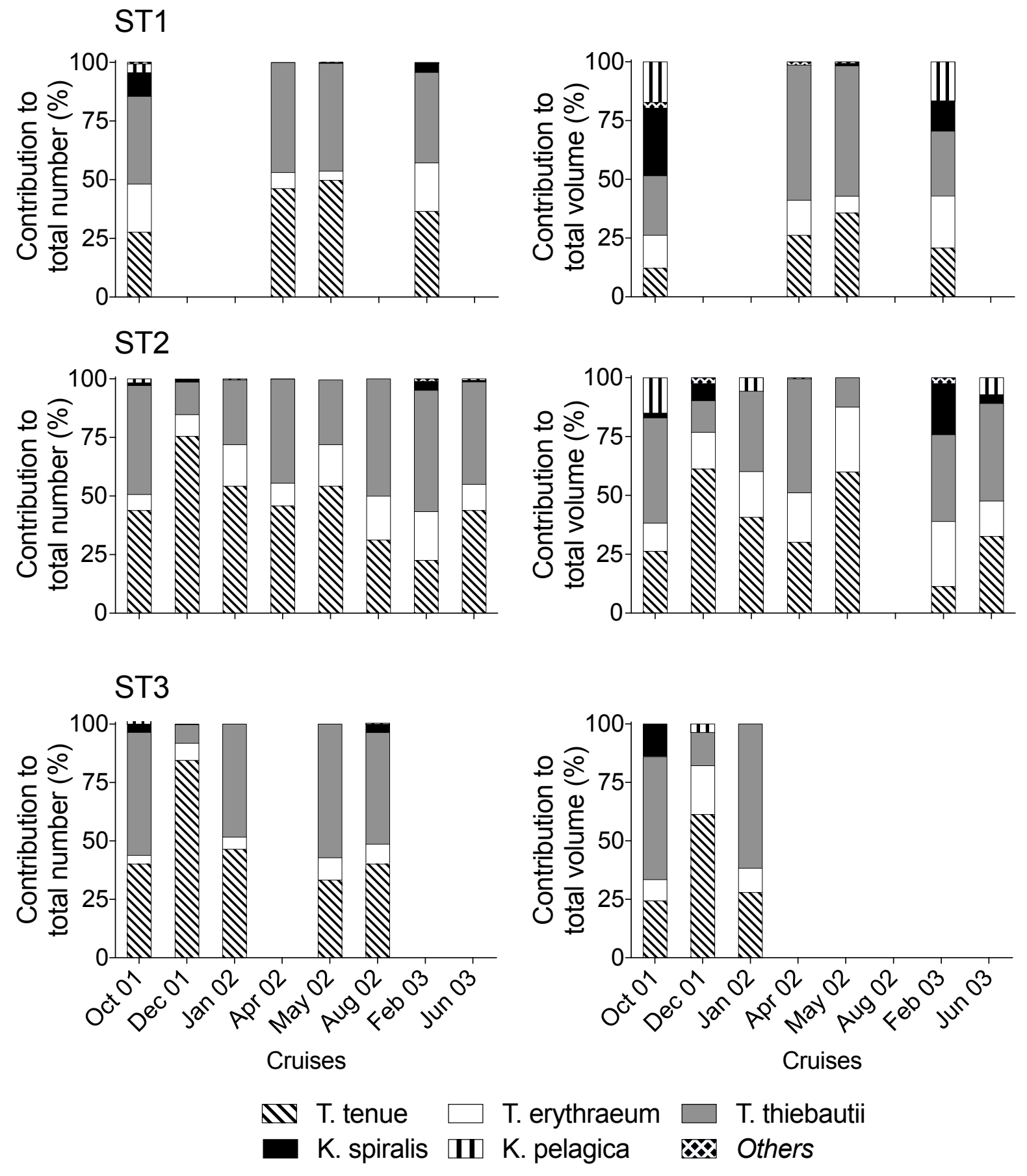

\section{IN T. tenue $\square$}

- K. spiralis

II

K. pelagica

Others 

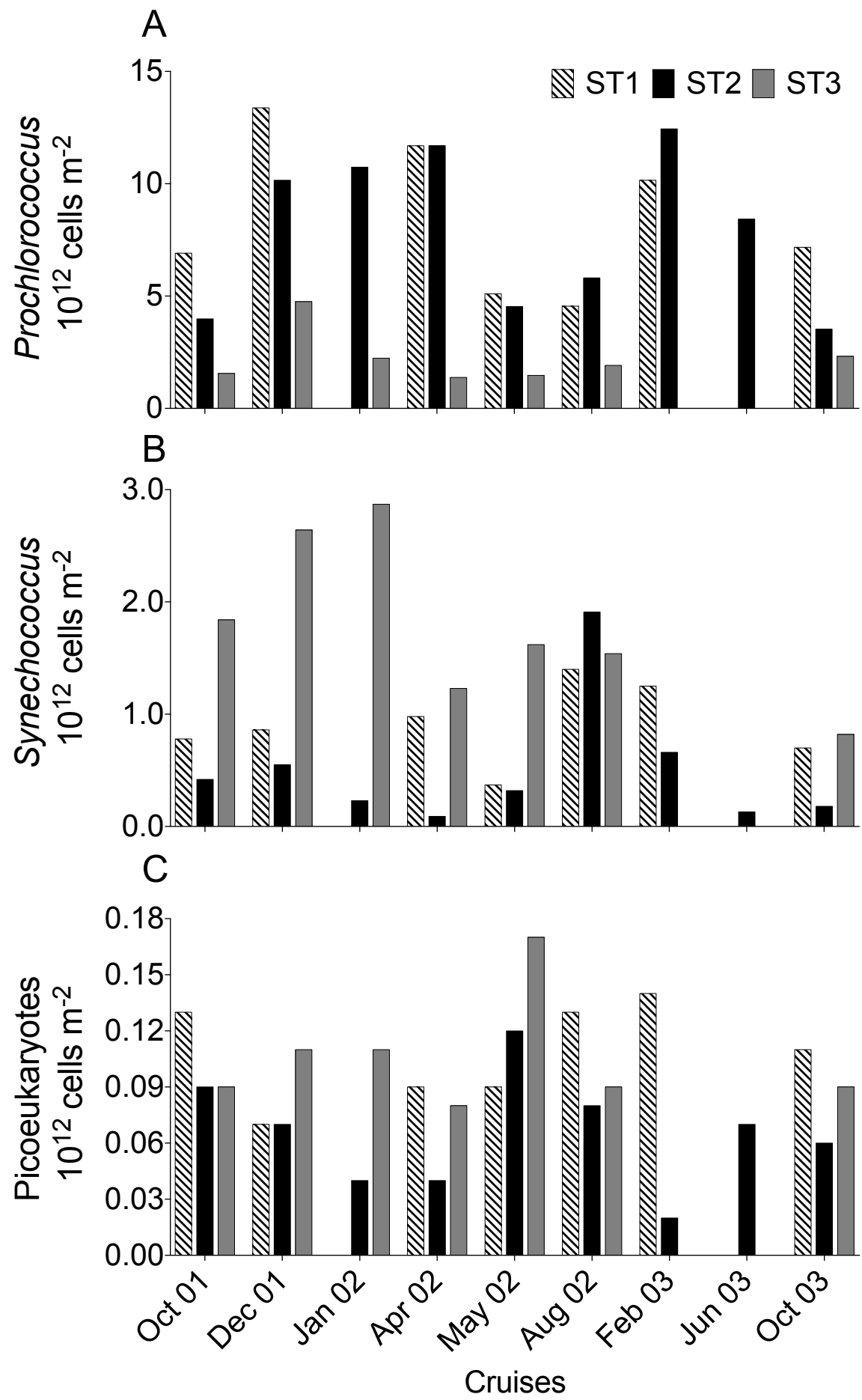

1091

1092

1093 Figure 9. Integrated concentrations of (A) Prochlorococcus, (B) Synechococcus, and (C)

1094 picoeukaryotes at the three stations sampled during the Diapalis cruises. Integration depths: 0-

$109560 \mathrm{~m}$ at ST1, ST2; 0-30 $\mathrm{m}$ at ST3. 

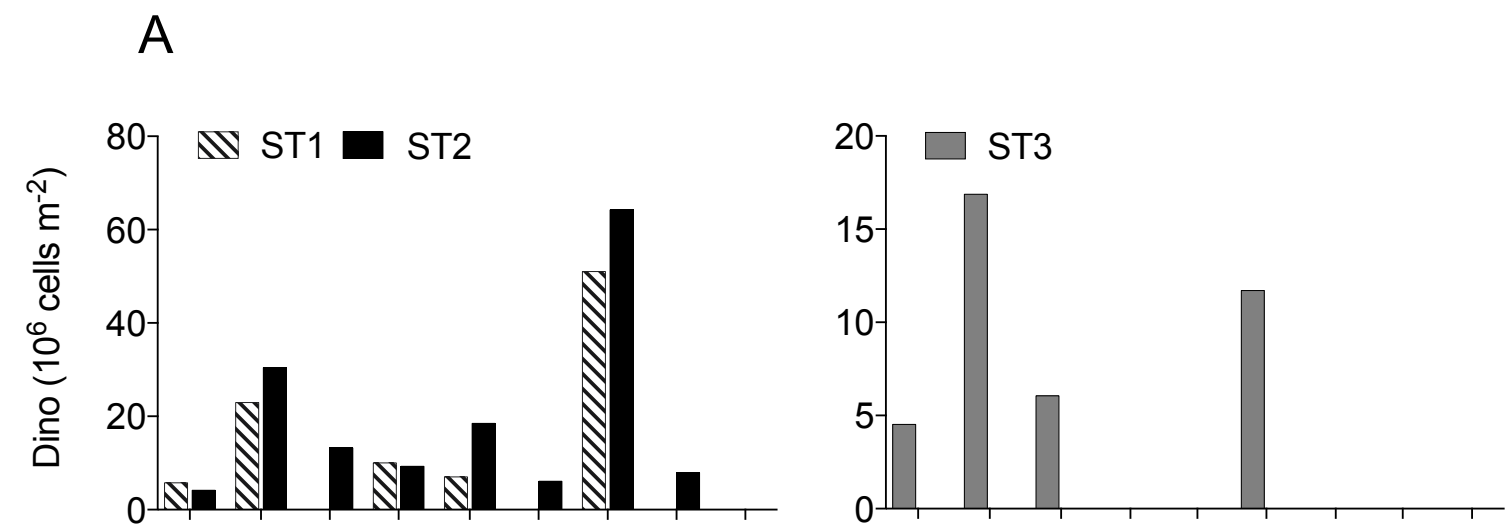

B
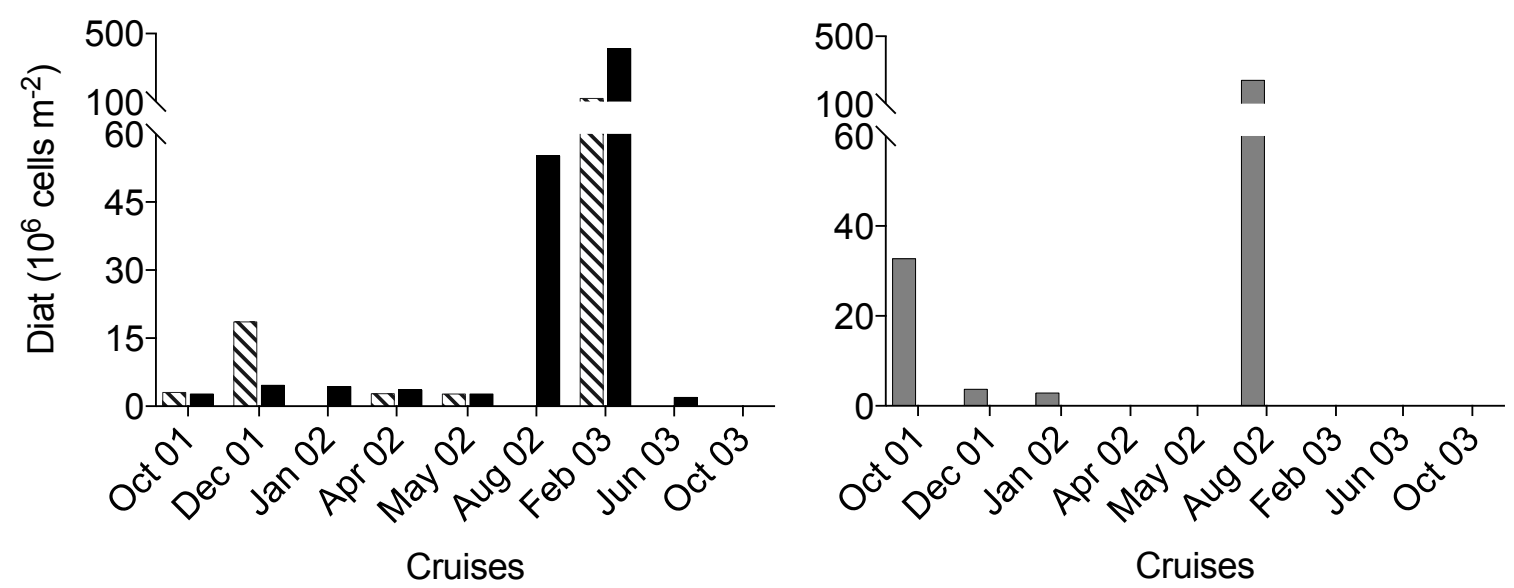

1098 Figure 10. Integrated concentrations of (A) dinoflagellates (Dino) and (B) diatoms (Diat) in the $1099>10 \mu \mathrm{m}$ fraction. Enumeration was carried out by inverted microscopy at the three stations 1100 sampled during Diapalis cruises. Integration depths: 0-60 m at ST1, ST2; 0-30 m at ST3. At ST2, integrated concentrations were determined at each cruise, except in August 2002. October 2003 abundance was too low for enumeration. Some cruises are missing at ST1 and ST3. 

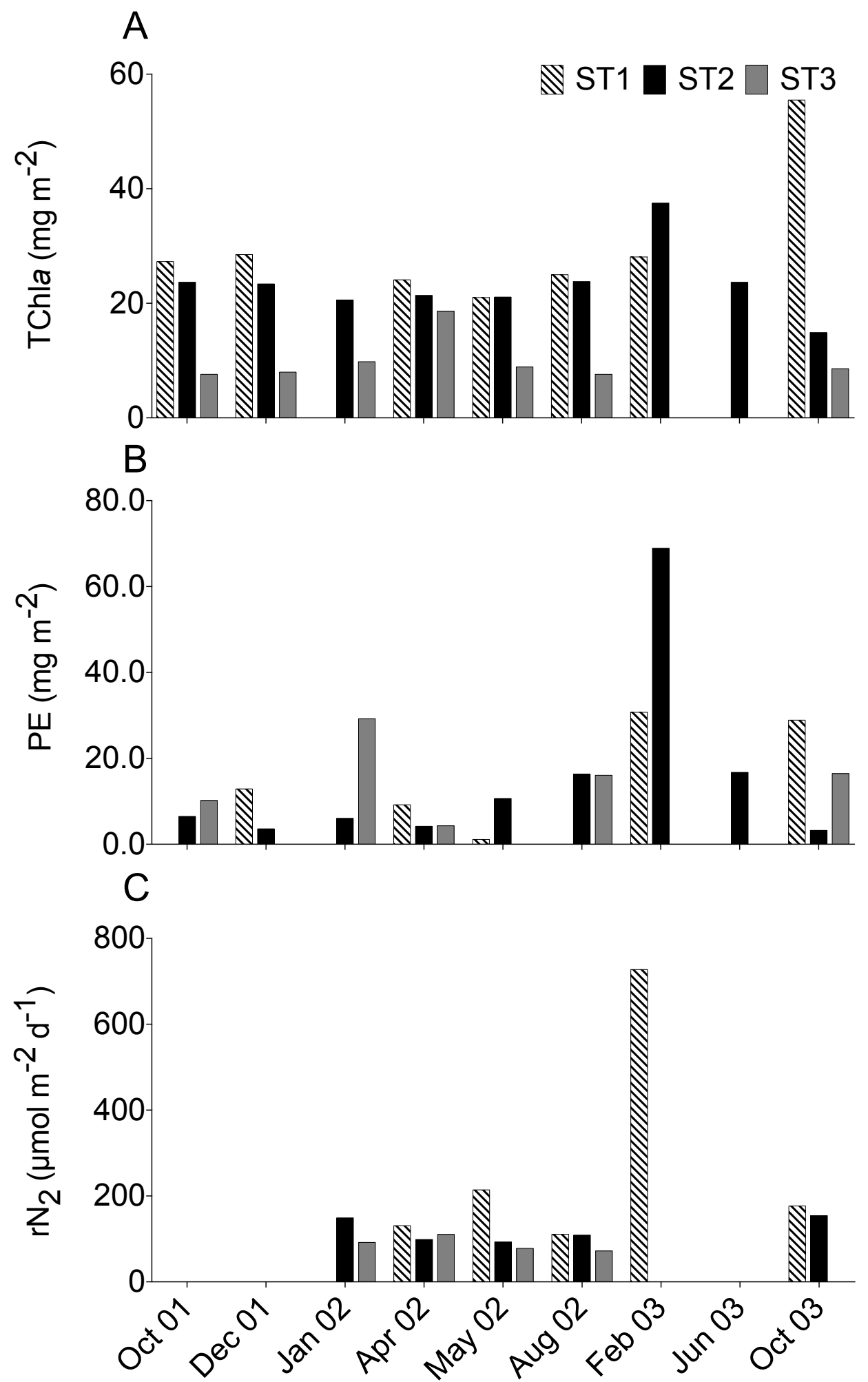

\section{Cruises}

1106 Figure 11. Integrated Tchla (A) and phycoerythrin (B) concentrations and (C) $\mathrm{N}_{2}$ fixation rates 1107 (Garcia et al. 2007) at the three stations sampled during the Diapalis cruises: Integration depths: $1108 \quad 0-60 \mathrm{~m}$ at ST1 and ST2, and 0-30 $\mathrm{m}$ at ST3. 
A
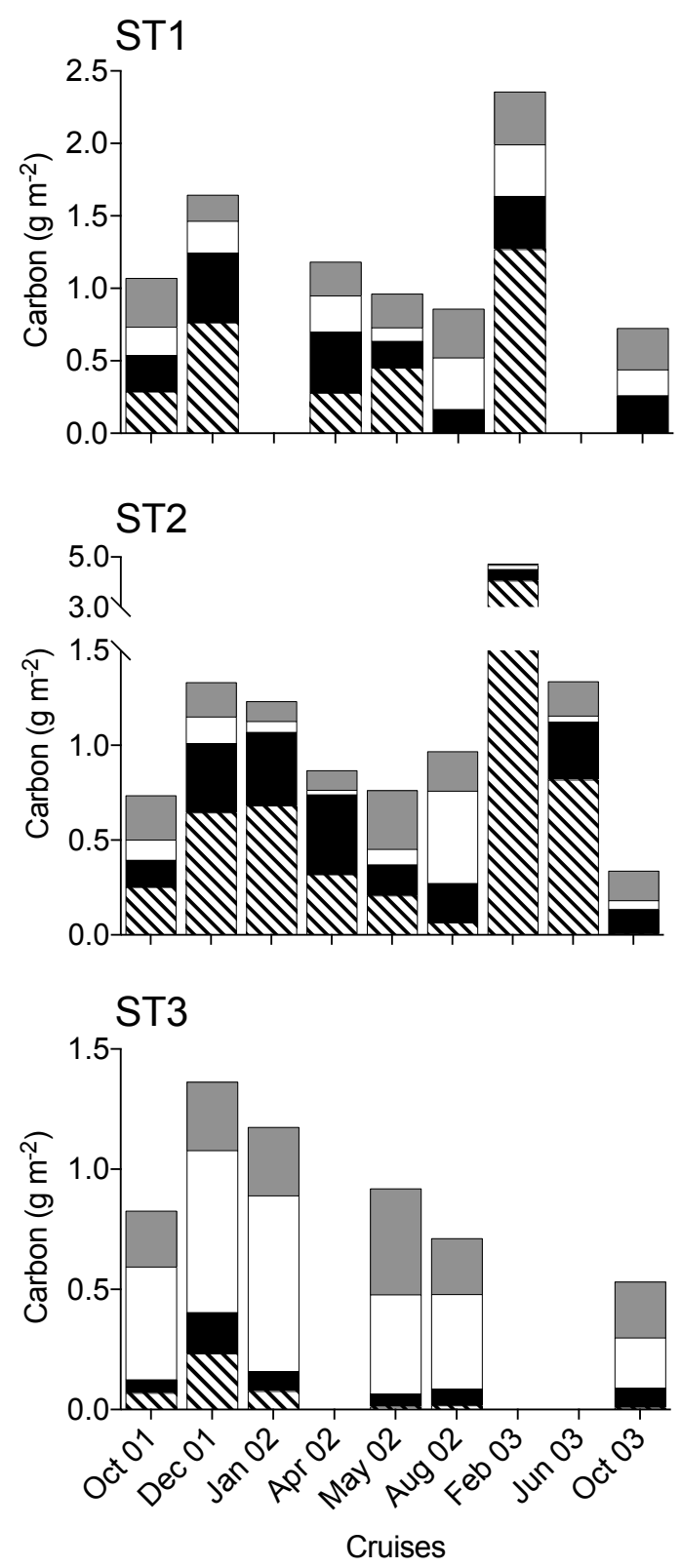

NV TK Proc
B
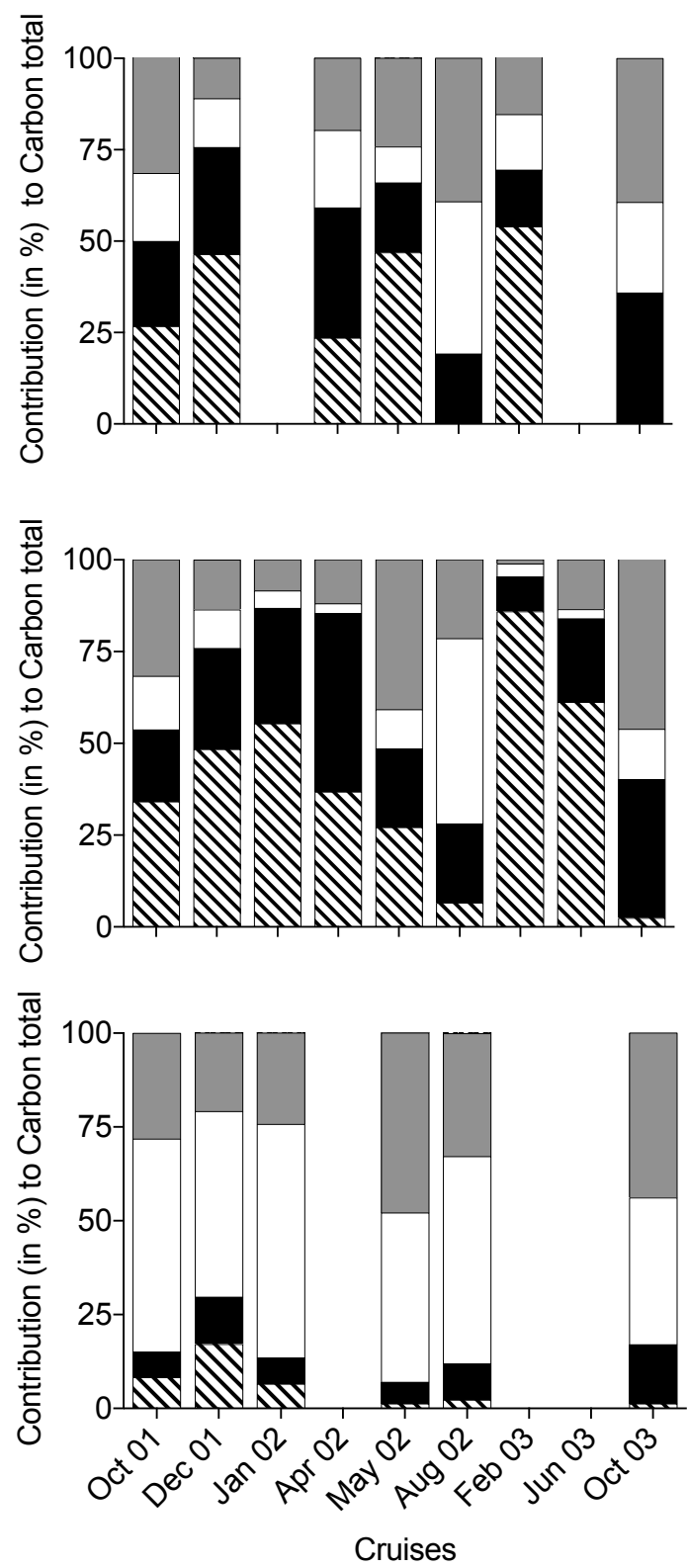

Syn $\square$ Picoeu RC

1113 Figure 12. A) Carbon biomass of picoplankton and filamentous cyanobacteria at the three 1114 stations sampled during the Diapalis cruises. The conversion factors were (fgC cell $\left.{ }^{-1}\right)$ : 1115 Prochlorococcus - Proc (36), Synechococcus - Syn (255), picoeukaryotes - Picoeu (2590), 1116 Richelia - RC (10), sum of Trichodesmium and Katagnymene - TK (17.22 $\left.10^{6} \mathrm{fgC} \mathrm{trich}^{-1}\right)$. B) 1117 Contribution of each group to the total carbon shown in A). 